\title{
Making a Global Image of the World: Science, Cosmography and Navigation in Times of the First Circumnavigation of Earth, 1492-1522
}

\author{
Antonio Sánchez \\ Autonomous University of Madrid \\ e-mail: antonio.sanchezm@uam.es \\ ORCID iD: https://orcid.org/0000-0001-8323-634X
}

Submitted: 3 February 2020. Accepted: 13 November 2020.

\begin{abstract}
The voyages of exploration and discovery during the period of European maritime expansion and the immense amount of information and artefacts they produced about our knowledge of the world have maintained a difficult, if not non-existent, relationship with the main historiographical lines of the history of early modern science. This article attempts to problematize this relationship based on a historical account that seeks to highlight the scientific and institutional mechanisms that made the Magellan-Elcano voyage, the first modern voyage, possible. The text argues that this voyage was the first modern voyage because it allowed the construction of a new scientific and cartographic image of the globe and contributed to our understanding of the world as a global world, altering the foundations on which modern European economic and geographic thought was based. In that sense, the voyage was something extraordinary, but not completely unexpected. It responded to a complex process of expansionary policy and technical development that dated back to the $15^{\text {th }}$ century, which in 1519 was sufficiently articulated to carry out a great feat.
\end{abstract}

KEYWORDS: long-distance voyage; astronomical navigation; scientific institutions; new scientific positions; cartographic artefacts; Magellan; early modern science.

Citation / Cómo citar este artículo: Sánchez, Antonio (2021) "Making a Global Image of the World: Science, Cosmography and Navigation in Times of the First Circumnavigation of Earth, 1492-1522." Culture \& History Digital Journal, 10 (2): e014. https://doi.org/10.3989/chdj.2021.014

RESUMEN: Construyendo una imagen global del mundo: ciencia, cosmografía y navegación en tiempos de la primera circunnavegación, 1492-1522. - Los viajes de exploración y de descubrimiento de la época de la expansión marítima europea y la enorme cantidad de información y artefactos que produjeron sobre nuestro conocimiento del mundo han mantenido una difícil relación, por no decir inexistente, con las principales líneas historiográficas de la historia de la ciencia moderna. Este artículo intenta problematizar dicha relación a partir de un relato histórico que pretende destacar los mecanismos científicos e institucionales que hicieron posible el viaje de Magallanes-Elcano, el primer viaje moderno. El texto sostiene que este viaje fue el primer viaje moderno no solo porque permitió la construcción de un mapa global del mundo, de una nueva imagen científica y cartográfica del globo, sino porque además contribuyó a nuestra comprensión del mundo como un mundo global, alterando los cimientos sobre los que se sustentaba el pensamiento económico y geográfico de la Europa moderna. En ese sentido, el viaje fue algo extraordinario, pero no completamente inesperado. Respondía a un complejo proceso de política expansionista y desarrollo técnico que se remontaba al siglo XV y que en 1519 estaba lo suficientemente articulado como para llevar a cabo una gran gesta.

PALABRAS CLAVE: viajes de larga distancia; navegación astronómica; instituciones científicas; nuevas posiciones científicas; artefactos cartográficos; Magallanes; ciencia moderna.

Copyright: () 2021 CSIC. This is an open-access article distributed under the terms of the Creative Commons Attribution 4.0 International (CC BY 4.0) License. 


\section{INTRODUCTION: MAGELLAN'S VOYAGE AND EARLY MODERN SCIENCE}

Last year, 2019, was the 500th anniversary of the departure of the Magellan-Elcano expedition, the famous voyage that went around the globe, always sailing westwards. 2022 will be five centuries since its return. The expedition departed from Sanlúcar de Barrameda (Cádiz) on September 20th 1519 heading west in pursuit of the Moluccas Islands, with five ships - old and in bad condition-, and returned almost three years later, ${ }^{1}$ on September 6th 1522, from the east with only one ship, the Victoria. The return of the Victoria to Seville shredded once and for all the geographical schemes of Aristotle and Ptolemy and empirically configured a new world map (Portuondo, 2019). This event was reflected by the famous Genoese cartographer Battista Agnese in one of his world maps of 1544 (Fig. 1). ${ }^{2}$ Spanish figures such as Pietro Martire d'Anghiera, Pedro de Medina, and Gonzalo Fernández de Oviedo, but also foreigners as Giovanni Battista Ramusio, among others, left a record of this historical episode. ${ }^{3}$

Generally, this event has been considered one of the great deeds of humanity, those that begin a new era. ${ }^{4}$ However, this has never been the case for the hegemonic historiography of modern science. ${ }^{5}$ Not even explicitly for those who put forward alternative explanations - more social and artisanal — of the emergence of modern science
(Zilsel, 1942). Therefore, it seems that this voyage and modern science were distant phenomena. It seems that being modern was a distinctive label belonging only to natural philosophers and observational astronomers who gave new explanations about the structure of the universe and not to those who discovered new worlds or circled the globe guided by the stars. Only a few isolated voices expressed the importance of going beyond the realm of physical-mathematical sciences to address other decisive contexts of social change in modern Europe, such as cosmography and navigation (Hooykaas, 1987).

The aim of the expedition was to find a sea passage in South America that would allow reaching the lucrative Spice Islands, an Indonesian archipelago located in the Pacific, the largest ocean on the planet, so large that it "went off the map." This required measurements to determine the distance of the Moluccas from the Tordesillas meridian. To do this, the expedition led by the Portuguese Ferdinand Magellan crossed the Atlantic, after passing through the Canary Islands, heading for South America in the hope of finding this passage and reaching the Moluccas by crossing the Pacific. This passage would open up a new commercial route with the East, always sailing in the area of the globe that was under Castilian jurisdiction as established in the Treaty of Tordesillas of 1494 (Moreno Madrid and Leitão, 2020). It would also end Portugal's commercial monopoly in Southeast Asia — which had in

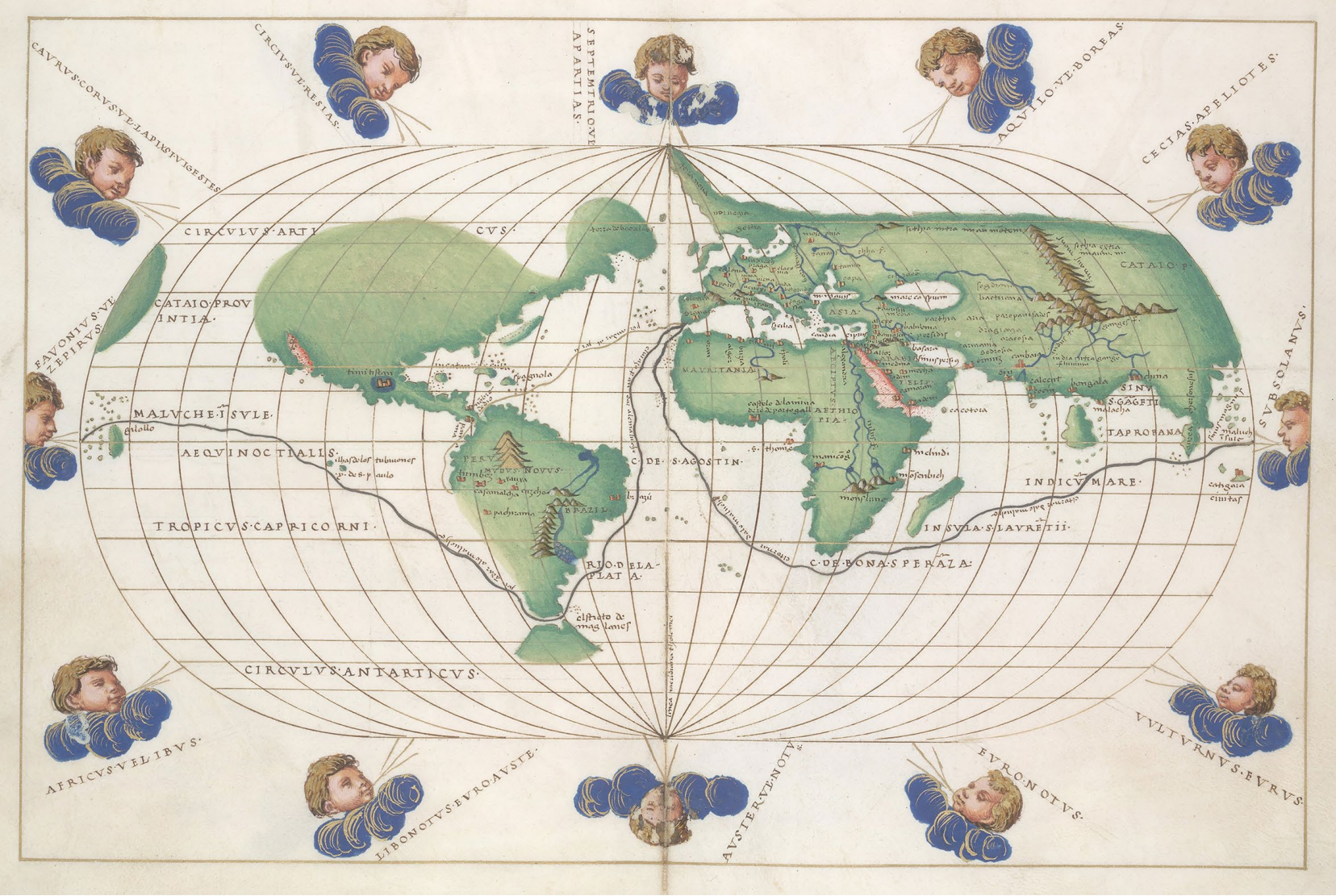

FIGURE I. Map of the world representing the itinerary of the Magellan-Elcano expedition, Batista Agnese, $c a$. 1544. From the Agnese's Nautical Atlas of the World. Manuscript on parchment. Huntington Library (San Marino, United States), HM 26. 
turn put an end to the Arab monopoly on spices in the same region (Díaz-Trechuelo, 1994).

This voyage has been interpreted on several occasions as a maritime adventure into the unknown led by brave, tough and fervent Catholic men with modest scientific knowledge (Higueras Rodríguez, 2018). However, what can be deduced from the documents related to the voyage is that this expedition was carefully designed by the imperial administration and was to be carried out based on the science of cosmography and the art of navigation, despite the fact that in most cases both depended on political decisions. ${ }^{7}$ In this sense, the expedition of Magellan-Elcano was also and, above all, a voyage of science and technology from day one of its preparation. In order to carry it out, it was necessary to incorporate among the crew "men of great science and experience" — as it was said in the nautical jargon - and to equip them with a significant number of scientific data, techniques and instruments. New regiments, nautical charts, astrolabes, quadrants, cross-staffs, compasses, and hourglasses, among many other devices, were produced. During the voyage, pilots and astronomers had to make use, as was usual in transoceanic journeys, of the observation and measurement techniques typical of astronomical navigation, that is, they had to calculate the height of the stars with the astrolabe to determine their latitude. This was a decisive aspect for the modern world (Albuquerque, 1988).

In the process of applying observational astronomy to ocean navigation techniques, it was necessary both to adapt the complex astronomical instruments already in existence for use on board and to simplify the methods of observation. The old astronomical astrolabes and quadrants, converted into nautical instruments during the fifteenth century, were limited to measuring angles to determine latitude. It was necessary to observe the height of the North Star during the night and to determine the meridian height of the Sun during the day. At an earlier stage, around the middle of the 15 th century, the Portuguese pilots measured the height of the North Star to know the displacement of the ship in a north-south direction from some point of reference. To do so, it was necessary to consult the North Star regiment. In a second phase of ocean navigation, the value of latitude could be known directly through simple rules that explained how to correct the height of the North Star, measured at sea or on land. This procedure became ineffective as soon as the ships headed for the southern hemisphere, where the North Star was progressively lost on the horizon. Faced with this inconvenience there was another way to find latitude: the observation of the Sun at noon. The observer could know its latitude thanks to the values of the height of the Sun over the horizon and the solar declensions. For it was enough to have the regiment of the declination of the Sun with tables of declinations for every day of the year. Taking into account that during the equinox the sun at noon reaches its zenith (the highest point in the sky from the point of view of the observer) being situated perpendicular to the equator (at $90^{\circ}$ of height), then it was enough to make a simple operation to know the latitude. It was enough to subtract at $90^{\circ}$ the height of the sun at noon from the position of the navigator who was making the observation. With this data, the pilots were able to determine their latitude at any point in the planet (Gaspar, 2012a). This was not something that was within the reach of the ancients.

This knowledge was already available in Magellan's time and had a long tradition. On the one hand, were known the solar tables of the Almanach Perpetuum (1496) by Abraham Zacuto, which served as models for the nautical tables made in Portugal. On the other hand, the two procedures to find the latitude were exposed in two anonymous navigation manuals at the beginning of the $16^{\text {th }}$ century, the two oldest known Portuguese nautical guides: the Regimento do astrolábio e do quadrante (ca. 1509) — known as Guia náutico de Munique - and the Regimento da declinação do Sol (ca. 1517) —also known as Guia náutico de Évora (Albuquerque, 1965).

Astronomical navigation changed the way in which to know the position of a ship in the middle of the ocean. The uncertain "point of fantasy" used in the Mediterranean, based on magnetic course and estimated distances, gave way to the "set point", based on magnetic course and calculation of observed latitudes. Both points provided the navigator with the position of the ship. However, these two methods resulted in significant errors when the physical phenomenon of magnetic declination, variable in time and space, was present. Representing the places within areas affected by magnetic declination according to their true latitudes and directions in relation to other places required a new cartographic model: latitude charts whose reference points had been incorporated according to observed latitudes (Gaspar and Sánchez, 2013).

In an attempt to strengthen the link between these scientific developments of maritime expansion and the modern world, the sociologist of science David Turnbull highlighted - in a widely cited article - the close relationship between cartography and modern science. Turnbull stated that the State and cartography created the conditions of possibility for modern science through what he calls "the assemblage of local knowledge" in new spaces, one of the fundamental characteristics of the production of scientific knowledge. To this end, he claimed the pioneering role of technical institutions on the Iberian Peninsula, such as the Casa da Mina in Lisbon and the Casa de la Contratación in Seville, which he considers to be the first scientific institutions in Europe (Turnbull, 1996). ${ }^{8}$

Following the trail of Turnbull's article, the present paper reconstructs the political motivations, the institutional framework and the technical-scientific developments that led to the realization of Magellan's voyage in 1519. More specifically, this text seeks to explain how the nautical and cosmographic knowledge possessed by Magellan and his men was developed and organized, as well as to show in what administrative and institutional structure it was sustained. In short, it tries to make explicit how this local nautical and cosmographic knowledge were assembled - using Turnbull's terms - in new spaces of science. The aim is to analyse the conditions of possibility of the first modern voyage in 16th centu- 
ry Europe. ${ }^{9}$ This voyage generated a global image of the world that allowed access to a geographical understanding of our planet (Portuondo, 2019, p. 329). This was, as Turnbull would say, a scientific task and, without a doubt, a very modern one.

\section{A GEOPHYSICAL PROBLEM: HOW TO START THE CAKE}

Magellan's voyage was presented as a response to a political-diplomatic and economic problem of great dimensions that was basically a problem of geophysical order: the Iberian distribution of the world. This problem went back, at least, to the Treaty of Alcaçovas-Toledo signed on September 4, 1479 between the Catholic Kings and Afonso $\mathrm{V}$ of Portugal. This treaty regulated the navigation in the African Atlantic and distributed the territories of the areas of influence of both kingdoms. The signing of the treaty made Portugal sovereign of the Atlantic islands and the lands of the African coast, that is, Guinea and its gold mines, the islands of Madeira, Puerto Santo, the Desertas, the Azores and the islands of Cape Verde. For its part, Castile would exercise its sovereignty over the Canary Islands, leaving open the possibility of exploring the western Atlantic. ${ }^{10}$

The Treaty of Alcaçovas-Toledo prevented Castilian sailors from sailing in the waters of the Atlantic that were south of the parallel that passed through the Canaries, but instead they could do so north of that parallel and, more importantly, to the west. This regulation always took place at a geographical and spatial level and, in short, in a scientific-technical register. The truce, which was premised on the agreement, for the rights of the Atlantic would last until March 1493, when Christopher Columbus returned to the peninsula with the news of his discovery. ${ }^{11}$ From then on, the aforementioned Iberian division of the world concentrated on an even more technical problem, the drawing of the demarcation line proposed by Columbus. This line was extracted from the Alexandrian bulls of 1493 clearly favourable to Castile ${ }^{12}$ - and, consequently, from the Treaty of Tordesillas signed the following year by the monarchs of Portugal and Castile. ${ }^{13}$ This event, which began in 1479, would give rise to a long dispute between the two maritime powers which would be settled much later with the unratified Treaty of Limits of 1750 and formalised in 1777 with the Treaty of San Ildefonso (Juan and Ulloa, 1972). This agreement was intended to forever put an end to the disagreements between the two crowns and to establish the borders (boundaries) between Spain and Portugal in South America. ${ }^{14}$

In the months leading up to the signing of the treaty, the dispute focused on determining what Columbus had discovered and where exactly it was. A map was required to show the partition line. To do this, the Catholic Kings requested the knowledge of expert cosmographers, such as Jaume Ferrer (Cerezo Martínez, 1994a, p. 176, 1994b, pp. 512-513; Gil, 1998; Millás Vallicrosa, 1991). The desired map - today lost-, in this case a nautical chart, arrived at the hands of Ferdinand and Isabella months before the meeting in Tordesillas (Varela Marcos, 1994, 1996 , p. 85). Not without discrepancies, Spanish and Portuguese historians have defended that both this chart and the chart —also lost — sent by Pêro da Covilhã to the Portuguese monarch John II from Cairo in 1491 contributed to the layout of the Tordesillas meridian (Cerezo Martínez, 1994b, p. 519; Cortesão, 1975, p. 51).

The voyage of 1519 was a direct consequence of all these disagreements and the Treaty of Tordesillas signed by the Catholic Kings and John II of Portugal on June 7, 1494. In this famous treaty, several relevant aspects were agreed upon that would affect Magellan's expedition. The Spanish Crown undertook not to send ships to the eastern part. The Portuguese Crown did the same for the western part. Any Castilian explorer who found new lands in an area dominated by the Portuguese flag or any Portuguese explorer who found new territories in the area of Castilian jurisdiction had to notify the discovery as soon as possible so that it could be conferred on its sovereign. It was also agreed to draw up a map with the parting line, a zero meridian that would cut in a straight line the Atlantic from north to south at 370 leagues west of the islands of Cape Verde, presumably from the island of San Antón, the westernmost one. ${ }^{15}$ This meridian line would simply reflect the territorial interests of both crowns. The lands east of the line would belong to Portugal and the rest to Castile. The line of demarcation would be fixed within a maximum period of ten months and for its determination, two or more caravels would be sent with astrologers and sailors who would go from Gran Canaria to Cape Verde in order to measure the 370 leagues to the west. However, in 1494 there was still no reliable method to determine the longitude accurately, as Transylvanus recalls. ${ }^{16}$ The establishment of a unit of measurement to compute the distance should not have posed serious problems at first, but it would cause them later with the discovery of the Moluccas.

Two nautical planispheres from 1502, the so-called Cantino planisphere and King-Hamy planisphere, represented the demarcation line on a map for the first time. The Cantino planisphere occupies a prominent place in this paper for two reasons. The first one, as has been mentioned, because it represents the meridian line of Tordesillas over the New World, next to which we can read Este he or marco dantre Castella and Portugal (this is the border between Castile and Portugal) (Fig. 2). To the west of the line three Castilian flags safeguard the lands of the Catholic Kings. To the east of the line, on Brazilian soil, two Portuguese flags — one at Cabo de San Jorge and the other at Puerto Seco and Vera Cruz - and a legend certify the discoveries made by Pedro Álvares Cabral. Also to the east of the partition meridian a series of flags mark the Portuguese and Spanish islands in the Atlantic, that is, the archipelagos of the Azores, Cape Verde and Madeira (without a flag) —on the one hand - and the Canary Islands - on the other.

The second one, because it constitutes a new geometric model. It is the first chart that incorporates observed latitudes according to the data offered by astro- 


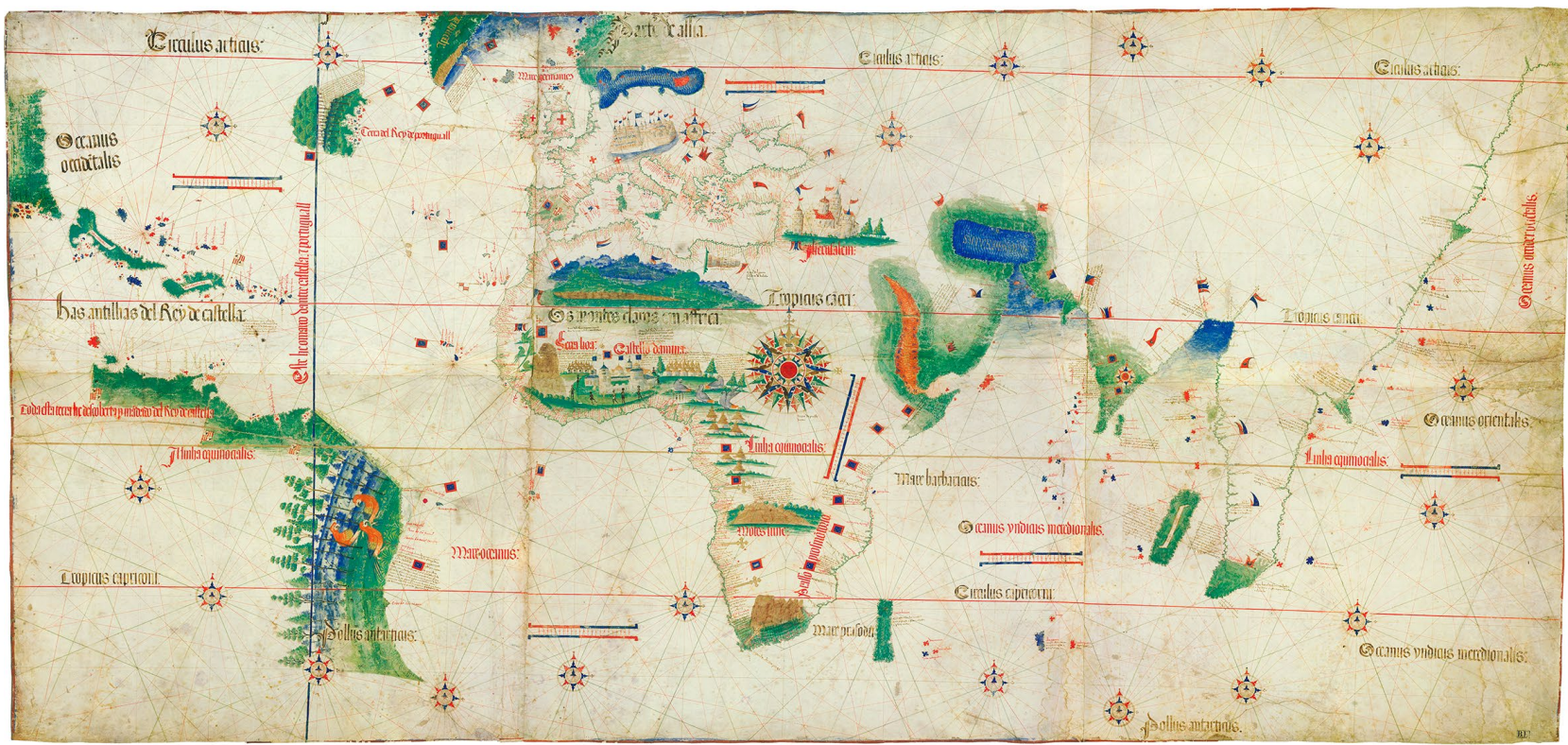

FIGURE 2. Cantino nautical planisphere (anonymous) representing the Tordesillas meridian, 1502. Estense Library, Modena (C. G. A. 2). Manuscript on parchment, 105 x $220 \mathrm{~cm}$.

nomical navigation. The incorporation of scientific data based on calculation and observation gave cartography and its mapmakers a status they could not have imagined before. This would be the way of making maps that would be adopted by the Casa de la Contratación some years later - with the arrival of Amerigo Vespucci and some Portuguese cartographers to Seville - to create the Padrón Real (Royal Pattern Chart) and to organize their oceanic voyages. On this basis, the cartography of Magellan's voyage would be made a few years later (Gaspar, 2012b; Sánchez, 2013, pp. 81-87).

Less famous is the King-Hamy planisphere, a chart of latitudes based on a Portuguese prototype and attributed to Amerigo Vespucci (Fig. 3). However, like the Cantino planisphere, the part of America was made up from information obtained in the Cabral expedition and Spanish explorations. It assumes the agreements signed in the Tordesillas pact and represents the partition meridian, incorporating the most up-to-date geographical information in the midst of the Portuguese-Spanish dispute (Levillier, 1954).

In the Treaty of Tordesillas, it was also established that the King of Portugal authorized the passage of Castilian ships through his area of influence when they were heading west, with the only condition that they did not stop to explore in Portuguese lands. In the same way, it was agreed that, if before June 20th of that same year of 1494 the Castilians found new places within the first 250 leagues of the line, these would henceforth belong to Portugal. If, on the other hand, they were within the next 120 leagues, up to the agreed 370 leagues, they would become part of Castile. In this way, the procurators of Castile and Portugal promised to fulfil the content of the capitulation, as well as the old Alcaçovas agreements. The representatives of both crowns swore to fulfil each of the conditions, putting God as their witness. Finally, within one hundred days each of the parties would deliver to the other the deed of the treaty with their approval and ratification (Tratado de Tordesillas, 1973, pp. 55-61; 2007; Albuquerque, 1973; Cortesão, 1973; Mota, 1973; Serrão, 1995).

Once Columbus had returned from his second voyage with the confirmation of the discovery of America, it was Portugal that urged the creation of a boundary line. However, when the Portuguese Pedro Álvares Cabral arrived in Brazil in 1500, the urgency also shifted to the Catholic Kings, especially once the conflict over the rights of spices was reopened. The Tordesillas meridian partially avoided the conflicts between Castile and Portugal in the Atlantic, but not in the Far East. In the first years of the 16th century, and as a consequence of the arrival of the Portuguese in India thanks to the route opened by Vasco de Gama in 1498, the idea of establishing an antimeridian was born. This idea was related to the possibility that there was another coastline to the western side of South America and, therefore, to the existence of a strait. The idea and the doubts about finding a maritime access to the west, but also the slowness in the exploitation of the riches of the East, and the successes of the Portuguese via their route to India led to King Ferdinand gathering in Toro (Zamora), in 1505 , three authorities related to the politics and cosmography of the Indies: the bishop of Palencia Juan Rodríguez de Fonseca, the navigator Vicente Yánez Pinzón, and the cosmographer Amerigo Vespucci. The meeting of experts held in Toro had as its main objective the reconsideration of the search for the strait that Columbus could not locate (Ezquerra, 1973; Lamb, 1974).

Despite its medieval character - based on the idea of the separation of two expansive and evangelizing powers - the Tordesillas meridian held a sign of modernity, as it attempted to establish a geographical and astronom- 


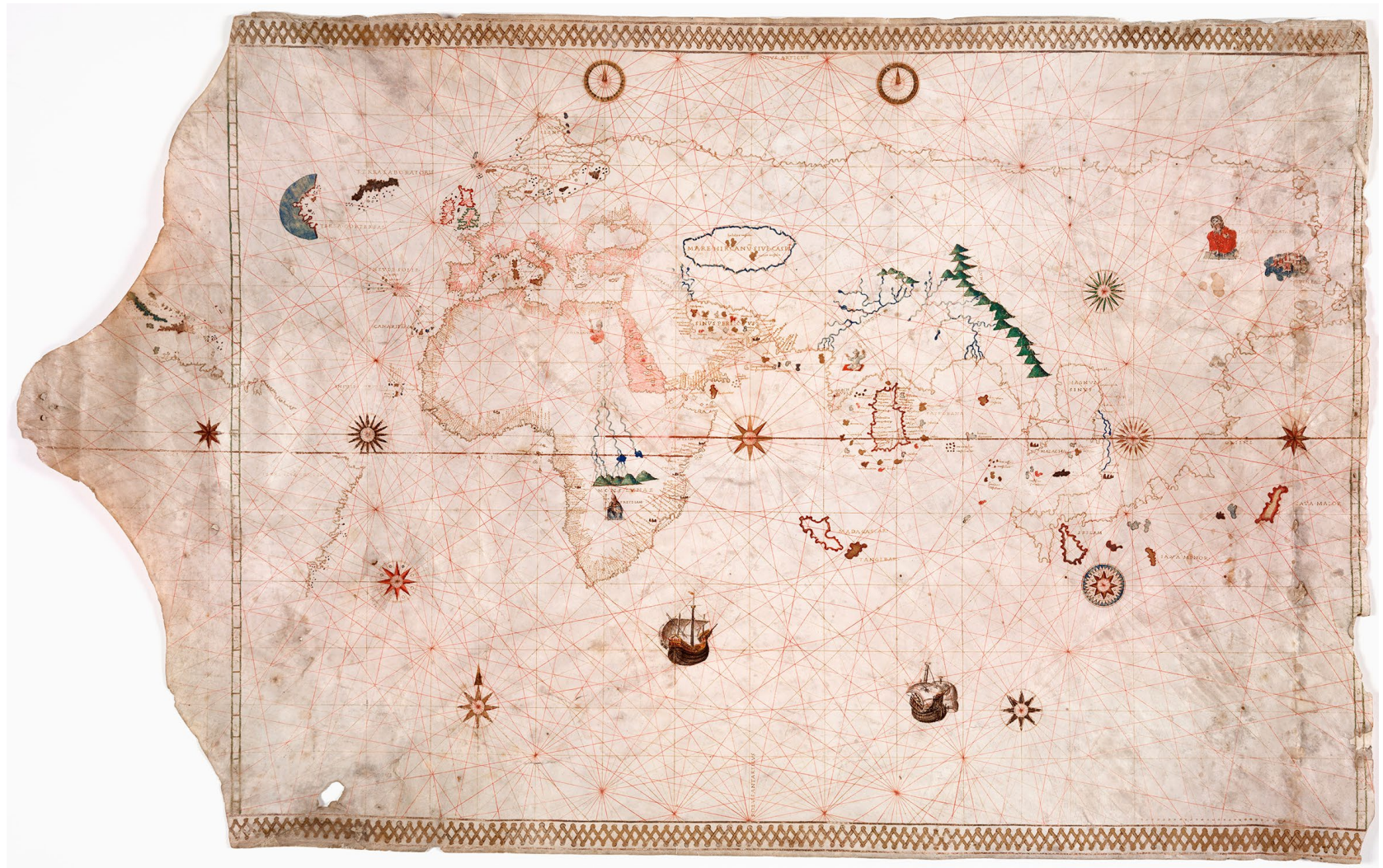

FIGURE 3. King-Hamy nautical planisphere (anonymous) representing the Tordesillas meridian [Amerigo Vespuci], ca. 1502. Huntington Library, San Marino (California). Manuscript on parchment, $58.5 \times 94.2 \mathrm{~cm}$.

ical boundary that described the contours of new lands (Muñoz Pérez, 1973, p. 202). In addition, it promoted the creation of other modern symptoms that we will see below.

\section{AN INSTITUTION, A POSITION AND A MAP: OR- GANIZING THE SCIENCES OF DISCOVERY}

Three years after the Junta (meeting of experts) of Toro, in March 1508, the King again convened, this time in Burgos, a new meeting in which, in addition to those present in Toro, the navigator Juan de la Cosa and the explorer Juan Díaz de Solís joined in. In Burgos, some measures adopted in Toro were ratified and, among other points, it was decided to create the office of Pilot Major of the Casa de la Contratación - the first scientific position of the young institution - and the Padrón Real - the official cartographic model of the Carrera de Indias (commercial sea route). In addition, in Burgos it was also decided to prepare an expedition that would reach a maritime passage towards the West. The experts of the Toro and Burgos boards had the difficult task of devising a strategy that would allow Castile to get ahead of Portugal in the lucrative exploitation of the spice trade. However, the decisions now had a different face. An institutionalised scientific framework supported them. In 1503, the Casa de la Contratación had been created to regulate and manage the commercial and technical affairs of the Indies. Moreover, in 1508 Vespucci — coming from Portugal - was appointed first Pilot Major of the Casa with the obligation to elaborate a model map called the $\mathrm{Pa}$ drón Real from which all the copies used by the navigators in their oceanic routes towards America had to be extracted (Sandman, 2007; Sánchez, 2013; García Redondo, 2018). Thus, since the early years of the 16th century, Seville had an institution of applied science, a scientific profession of high qualification and a cartographic model to provide regulatory support for any political-diplomatic decision. Something similar took place in Portugal, and probably earlier, with the Armazéns da Guiné and Índia, the position of Cosmógrafo-Mor (Chief-Cosmographer) and the cartas padrões d'el Rei (standard charts) (Sánchez, 2016, 2018).

In the meetings of Toro and Burgos, the idea of a voyage like the one of Magellan-Elcano began to take shape (Fernández Navarrete, 1944). Around 1512 the Portuguese had already sailed through India and Malaysia and news was beginning to arrive that a certain Francisco Serrão, a good friend of Magellan, had arrived in the Moluccas. In 1510, an anonymous Portuguese cartographer, perhaps Jorge Reinel, depicted the Moluccas for the first time on a chart of the Indian Ocean (Ozanne, 1989) (Fig. 4). Three years later, Francisco Rodrigues, Chief Pilot of António de Abreu's navy, represented the Spice Islands on six of the twenty-six nautical charts that make up his atlas (Garcia, 2008) (Fig. 5). Two years later, the Portuguese apothecary Tomé Pires described for the first time the new islands and their riches in his Suma Oriental. At that 


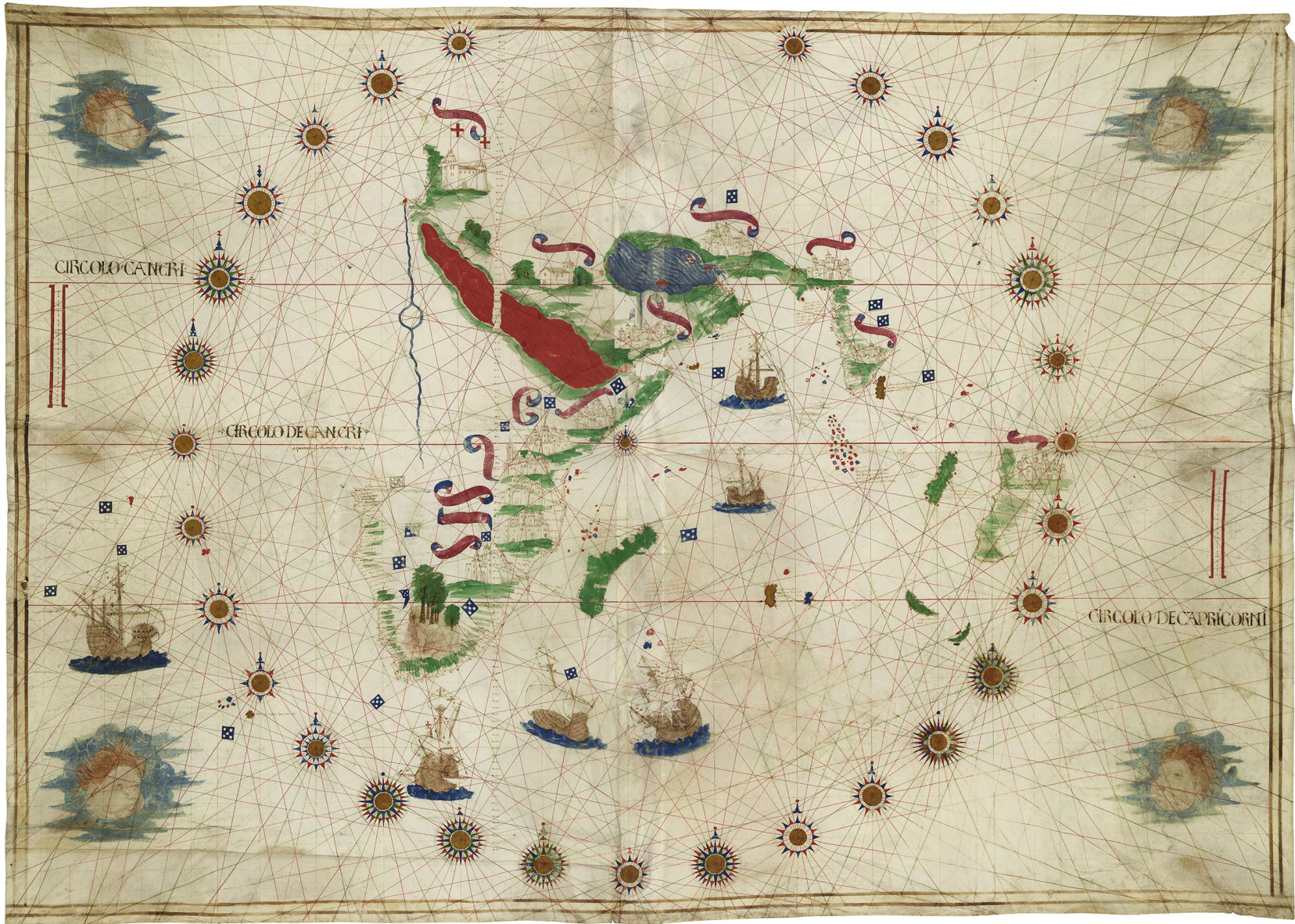

FIGURE 4. Chart of the Indian Ocean representing the Moluccas Islands [Jorge Reinel], c. 1510. Herzog August Bibliothek, Cod. Guelf. 98 Aug. 2. Illuminated manuscript on parchment, $160 \times 115 \mathrm{~cm}$.

time, the Spanish Vasco Núñez de Balboa discovered the so-called South Sea (Pacific Ocean). The bull Praeclarae devotionis by which Pope Leo X granted Portugal in 1514 the lands of the East further complicated the situation of Castile in Southeast Asia. For fear of the progressive Portuguese incursion into the East, King Ferdinand proposed in 1512 to the new Pilot Major of the Casa Juan Díaz de Solís - substitute of Vespucci- an expedition to the west of Castilla del Oro, in the northern part of South America, where they hoped to find a sea passage to the west. As had already happened in 1494, the question now was: where would the line of demarcation in the eastern hemisphere pass if it were elongated around the earth's sphere like a ring? The voyage did not materialize until 1515, when Solis was entrusted with the search for such a passage to the newly discovered South Sea, this time from the southern coast of Brazil. Solis' death at the hands of a group of natives in the Rio de la Plata ended the expectations of the Spanish crown.

The diplomatic war between Spain and Portugal placed cartography at the centre of the battle (Marques de Almeida, 1995). The cunning and ingenuity of cartographers awakened the territorial awareness of rulers while their territorial needs led to a growing sense of space.
The very usefulness of maps for the official interests of the Court stimulated a new cartographic conception of administration, no longer directed only to the practical purposes of navigation but also to the convulsed world of political diplomacy (Sandman, 2001, pp. 26-91).

The early Portuguese cartography of the Moluccas was followed by other charts made by Pedro Reinel and his son Jorge, where the Spice Islands were always located in the Portuguese hemisphere and only exceptionally in the Spanish hemisphere (Cortesão, 1975). Thus, in the years prior to Magellan-Elcano's voyage, a fervent cartographic struggle between Spanish and Portuguese interests to locate the islands where appropriate was initiated. The most controversial places were always those located near the meridian and the antimeridian of Tordesillas. Brazil and the Moluccas played a leading role throughout the sixteenth century in a host of political and geographical controversies between the Portuguese and the Castilians. If the Castilians tried to move the Moluccas towards the Spanish hemisphere, the Portuguese tried to extend the territorial extension of Brazil. ${ }^{17}$

One of the maps that locate the Moluccas on the Spanish side is the so-called "Kunstmann IV", an anonymous planisphere attributed to Jorge Reinel and made in 


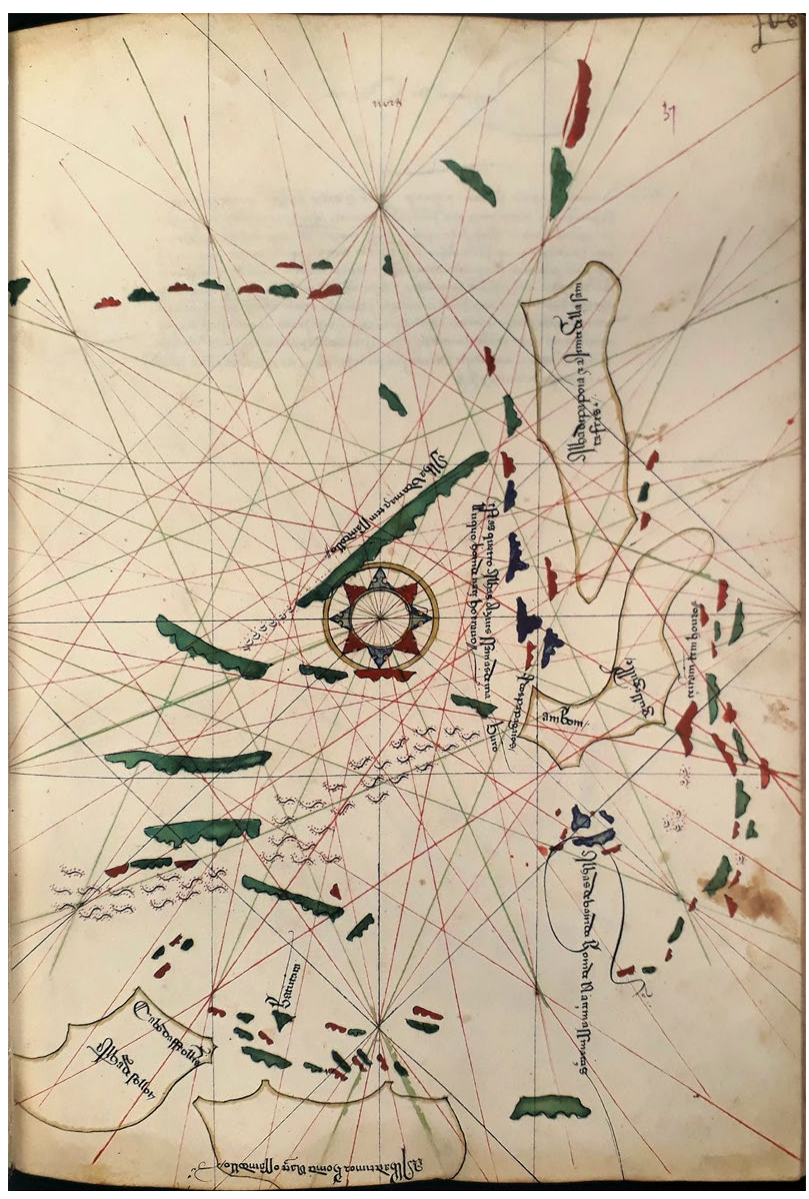

FIGURE 5. Nautical chart representing Eastern Insulinde with the Moluccas, by Francisco Rodrigues. Livro de Francisco Rodrigues, ca. 1513. National Assembly of France, Ms 1248. E/D 19.

1519 , the year in which the Reinels were in Seville working on the preparation of Magellan's expedition. The art and science of making maps was at the center of the problem. However, to see the antimeridian on a map we would have to wait for the results of the voyage.

When Magellan arrived in Castile in 1517 with the intention of presenting his plan to Charles I, he was not alone. His act of disloyalty and betrayal towards Portugal was about to be consummated and required scientific collaboration. ${ }^{18}$ Some cartographic material and a rich retinue of Portuguese cosmographers, cartographers, and navigators, among whom were the brothers Rui and Francisco Faleiro, Pedro Reinel, his son Jorge (Reinel) and Diogo Ribeiro accompanied his expeditionary project (Gil, 2009, pp. 239-413). Some Spanish historians and chroniclers echoed the cartographic material that Magellan brought from Portugal to persuade the King of Castile, of whom João de Barros affirmed, "he was in love with charts and pomas de marear" (Barros, 1777, book V, chap. 8 , p. 629). The first of them, Bartolomé de las Casas, affirmed that "Magellan brought a well painted globe, in which all the earth was shown, and there he pointed out the path that he was to take, except with the strait left [...] in white, because someone had not altered it" (Las Casas, 1876, p. 377). Later Antonio de Herrera repeated the information given by Las Casas: "Magellan brought a well painted globe, where all the earth was well shown, and there he pointed out the path he was to take, and he left the strait blank because it could not be altered" (Herrera, 1601, p. 66). Shortly after Herrera, Bartolomé Leonardo de Argensola pointed out:

On his return to Portugal [Magellan], he was not made to suffer. Previously, he was judged to have been wronged, and with a feeling of umbrage, he went to Castile, bringing a planisphere drawn by Pedro Reinel. By which, and through conferences, which he had had with Serrano by letter, he persuaded the Emperor Charles V that the Moluccas were his right. It is said that he confirmed his opinion with the writings and authority of the Portuguese Rui Faleiro, judicial astrologer, and also with that of Serrano (Argensola, 1609, p. 16).

According to the chronicler of the voyage Antonio Pigafetta (also known as Antonio Lombardo), Magellan was able to defend the existence of a strait "because he had seen it on a marine chart of the King of Portugal, a map which had been made by a great pilot and mariner named Martin of Bohemia" (Stanley, 2010, p. 58). Nevertheless, the truth is that at that time only a globe made by Johannes Schöner in 1515 represented the longed-for sea passage to the Moluccas (Van Duzer, 2010) (Fig. 6).

Little is known about the cartographic preparation of this project beyond these late testimonies, which were likely aware of the missive sent on July 18, 1519 by Sebastião Álvares, Factor of the King of Portugal in Seville, to King Manuel I. In that letter, Álvares informed the king with displeasure not only of the itinerary planned by Magellan, but also of the fact that he had seen the Moluccas represented in a nautical chart drawn up by Jorge and Pedro Reinel. Álvares' letter confirms not only that the Reinels carried out a cartographic work in Seville in the months prior to the departure of the expedition. It confirms also that they left there a cartographic model with the representation of the Moluccas that would later be followed by the person who would become a prestigious cartographer of the Casa, the Portuguese Diogo Ribeiro. ${ }^{19}$

Álvares' letter indicates that, in the summer of 1519, a few weeks before the departure of the expedition, there was already at least one nautical chart in Seville where the Moluccas, the main objective of the expedition, could be seen. We do not know if the islands were represented on the Spanish or Portuguese side, as Álvares does not make this explicit. This chart could have been the anonymous planisphere of Munich (Cortesão and Mota, 1987, pp. 1921) (Fig. 7). This planisphere, better known as Kunstmann IV, represents the world discovered by Europeans at the end of the second decade of the 16th century. The author of the chart represents the western coast of the Isthmus of Panama, discovered by Nuñez de Balboa in 1516-1517, but not the Strait of Magellan, two facts that have allowed 


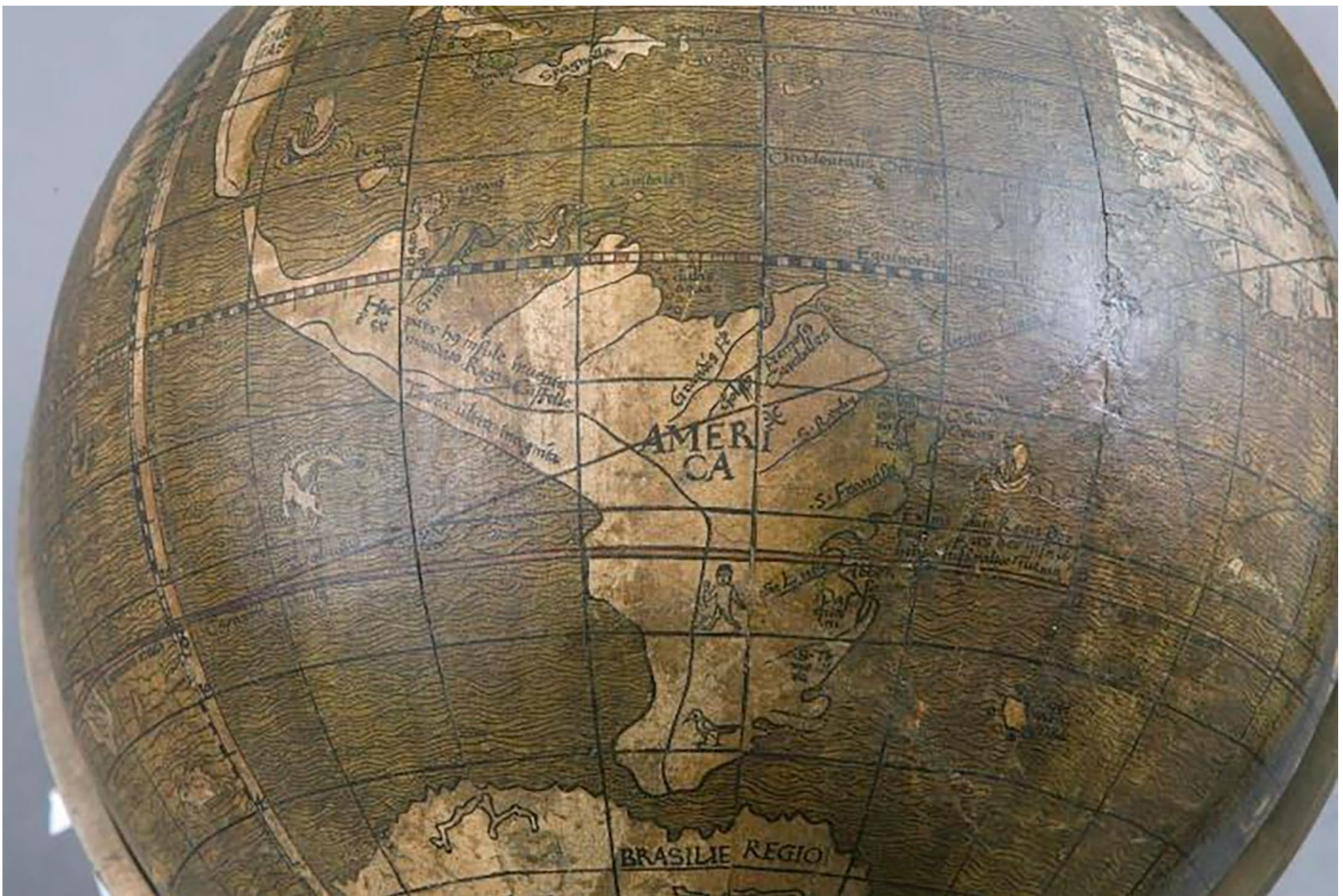

FIGURE 6. Representation of a strait in South America on Johannes Schöner's globe, 1515 (27 cm in diameter). Historisches Museum, Frankfurt (Germany), HMF X 14610.

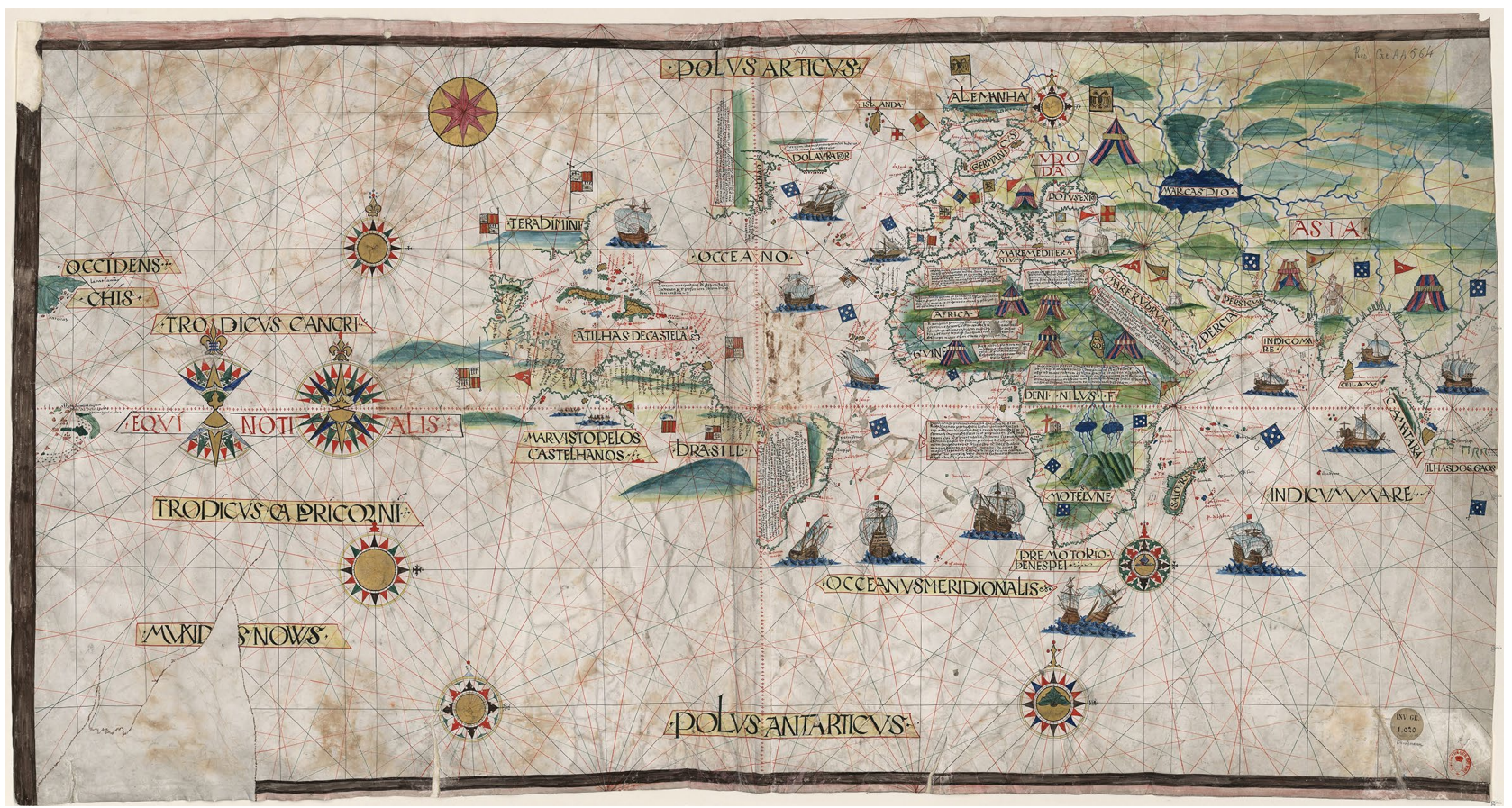

FIGURE 7. Anonymous planisphere of Munich representing the Moluccas Islands (Kunstmann IV) [Jorge Reinel and Pedro Reinel], ca. 1519. Facsimile of 1843, Bibliothèque nationale de France, GEAA564 (RES). Illuminated manuscript on parchment, 65 x $124 \mathrm{~cm}$. 


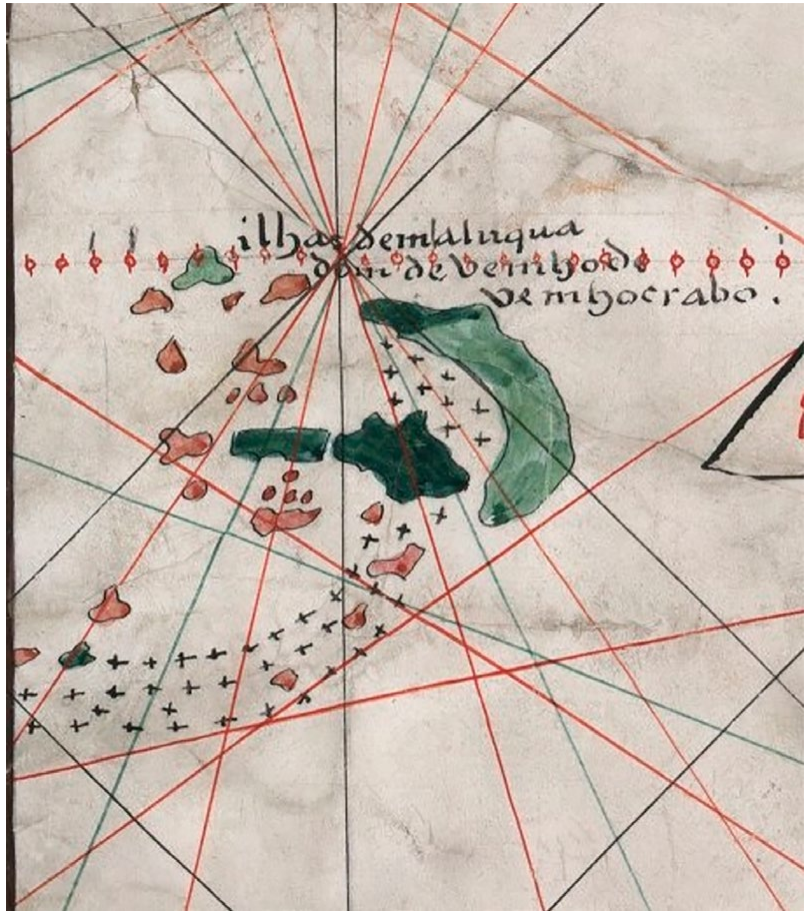

FIgURE 8. Detail of the Moluccas Islands on the anonymous planisphere of Munich [Jorge Reinel and Pedro Reinel], ca. 1519. Facsimile of 1843, Bibliothèque nationale de France, GEAA564 (RES). Illuminated manuscript on parchment, $65 \mathrm{x}$ $124 \mathrm{~cm}$.

specialists to date the planisphere with relative accuracy. Apart from being the first known map with the graduated equator, the most outstanding aspect of this planisphere is that it located the Moluccas to the east of the demarcation meridian, that is, in the Spanish hemisphere (Fig. 8). ${ }^{20}$

This planisphere has a double virtue. Firstly, it synthesises the context prior to the preparation of the Magellan-Elcano expedition, which was marked by three main episodes: the Treaty of Tordesillas and the meridian, the Moluccas dispute and the antimeridian, and the search for a strait that would end the Portuguese trade monopoly in the East. ${ }^{21}$ Secondly, it projected the future cartographic works of the Casa and the voyage of 1519 (Sánchez, 2009).

\section{The Casa de la Contratación, the Pilot Major, and the Royal Pattern Chart}

The Casa de la Contratación was the body that gave scientific and institutional support to the Magellan project. It was in this institution that the navigator's Portuguese entourage had found refuge. They were the officers of the Casa who, with more or less misgivings, with more or less acquiescence, had to make available to Magellan all that was necessary for the preparation of the voyage. From at least 1508, when the post of Pilot Major and the Padrón Real were created, there existed in the Casa a department of cosmography whose functions included the scientific-technical preparation of long-distance voyages, that is, the commercial voyage of the Carrera de Indias and other expeditions of discovery to the New World. This department was to be responsible for the training of sailors and the supply of nautical instruments. Among these instruments, the nautical charts copied from the Padrón Real occupied a prominent place. The Padrón Real was a general cartographic model of the world - a planisphere - from which the Casa cartographers extracted copies of certain regions of the globe (Sandman, 2007; Sánchez, 2013; García Redondo, 2018).

We know that the cartographic and instrument building activity was very intense in the months prior to Magellan's voyage. Rui Faleiro himself was in charge of it. All these activities had to be carried out under the strict control of the Pilot Major that at the time of the expedition was the Venetian Sebastian Cabot, who had replaced in 1518 the Portuguese fugitive Juan Días de Solís, discoverer of the River Plate. Thus, the Casa prepared the voyages by supplying it with the necessary scientific equipment, monitored it from a distance and then managed the new geographical information brought by the expeditions.

The establishment of the Casa in 1503 and the joint creation of the post of Pilot Major and the Padrón Real five years later was a crucial event for the development of the Magellan-Faleiro project. Despite the fact that the project had been designed far from Seville, the royal Castilian administration had to give it shape and materialise it. In this sense, the Casa de la Contratación and its technical and administrative mechanisms played an essential role in the development of the expedition. The Casa's administrative infrastructure provided the Magellan expedition and other contemporary expeditions - such as that of Gil González Dávila to the South Sea from Central American territories in 1522 - with a "heterogeneous engineering" framework where they assembled "practices, instrumentation, documents, theories and people", as Turnbull reminds us. The Casa "brought together a range of experts (cosmographers, astronomers, navigators and pilots, ship's masters, instrument makers and cartographers) and a variety of instruments, navigational techniques, tables and methods of calculation, as well as the diverse observations and practical experiences of all kinds of mariners" (Turnbull, 1996, p. 9). This human and material assembly of scientific resources must also be considered by those who characterize Magellan's enterprise and other enterprises of the same period as disorganized nautical adventures driven by recklessness, imprudence, violence, barbarism, greed, debauchery and religious fanaticism.

\section{THE VOYAGE: BEYOND ADVENTURE}

The problems derived from all the previous events caused King Charles I to accept the proposal, made by Magellan and Rui Faleiro in Valladolid, ${ }^{22}$ to reach the coveted Moluccan Islands by sailing in the South Sea. ${ }^{23}$ As has already been said, Magellan arrived in Seville with a large group of specialists in the field, some of whom would accompany him on his expedition. Among them were astronomers, astrologers, navigators, cosmographers 
and cartographers, several of them great names from the Iberian cosmography of the 16 th century. The navigator and the failed cosmographer defended the viability of their project with cartographic material that placed the eastern islands in the Castilian part. Thus, the main objective of the voyage would be of geographic character, that is to say, to place the Moluccas within the framework of the new idea of the antimeridian and to clarify later, with maps, to whom they belonged. This was stated in the instructions given by the king on August 9, 1519, a few days before the departure. ${ }^{24}$ Convinced of the importance that this project had for the Castilian aspirations and for himself, the young emperor ordered the expedition be organized. The Knight of the Order of Santiago, who knew the East and was skilled in both the art of the sword and the compass, and the erudition of Faleiro had convinced him.

\section{The scientific preparations}

Thus, five hundred years ago the port of Seville was preparing, with its fervent nautical activity, to launch into the Atlantic - as on so many other occasions - the five ships of the great expedition. This intense nautical and commercial activity was perfectly captured in the View of the city of Seville, a topographical image from the end of the 16th century attributed to Alonso Sánchez Coello (Fig. 9). So often used to allude to the world of transatlantic sailing, the realistic image of the port of the city of Seville on the banks of the Guadalquivir quickly puts us in context and allows us to be transported, even momentarily, to 16th century Seville, one of the richest and most powerful urban centres in modern Europe. When we look closely at this view of Seville we have the feeling of being able to hear the daily hustle and bustle of the nautical activity, with its rowing galleys and ships, its shipyards and its hectic commercial and artisanal élan vital. Not very different from this reality must the atmosphere have been in which Magellan's trip was organized.

The preparations for the expedition were being made by a major scientific and technical company whose economic investment - from the Crown, from major German investors such as the Fuggers and the Welsers, and from Burgos merchants such as Christopher of Haro had reached very high levels. ${ }^{25}$ The money invested in the provision of the five ships of the armada exceeded 8,000,000 maravedís -including ships. Of that amount, more than 68,000 maravedís were spent on making nautical charts on parchment, wooden and metal quadrants and astrolabes, compasses and hourglasses. Most of this money was used to buy skins for the charts, to pay the cartographer Nuño García de Toreno to make twenty-four charts and to purchase the planisphere sent to the king. Unfortunately, we know nothing about the whereabouts of this material.

Sixty-eight thousand one hundred and eighty-two maravedís have been spent on the nautical charts and quadrants going into the armada, as follows: 1,125 maravedís that were given to Nuño García to buy parchments to make charts. 900 for a dozen parchments that were given to the said [Nuño Garcia]. 864 maravedís the cost of another dozen skins that were given to the said Nuño García. 13,125 maravedís for seven charts that he made on the order of Rui Faleiro, five ducats each one. 11,250 maravedís that were paid to Nuño García for eleven charts that he made on the order of Ferdinand Magellan. 13,500 maravedís for another six charts that Rui Faleiro made, with one that he sent to His Royal Highness [...] 4,500

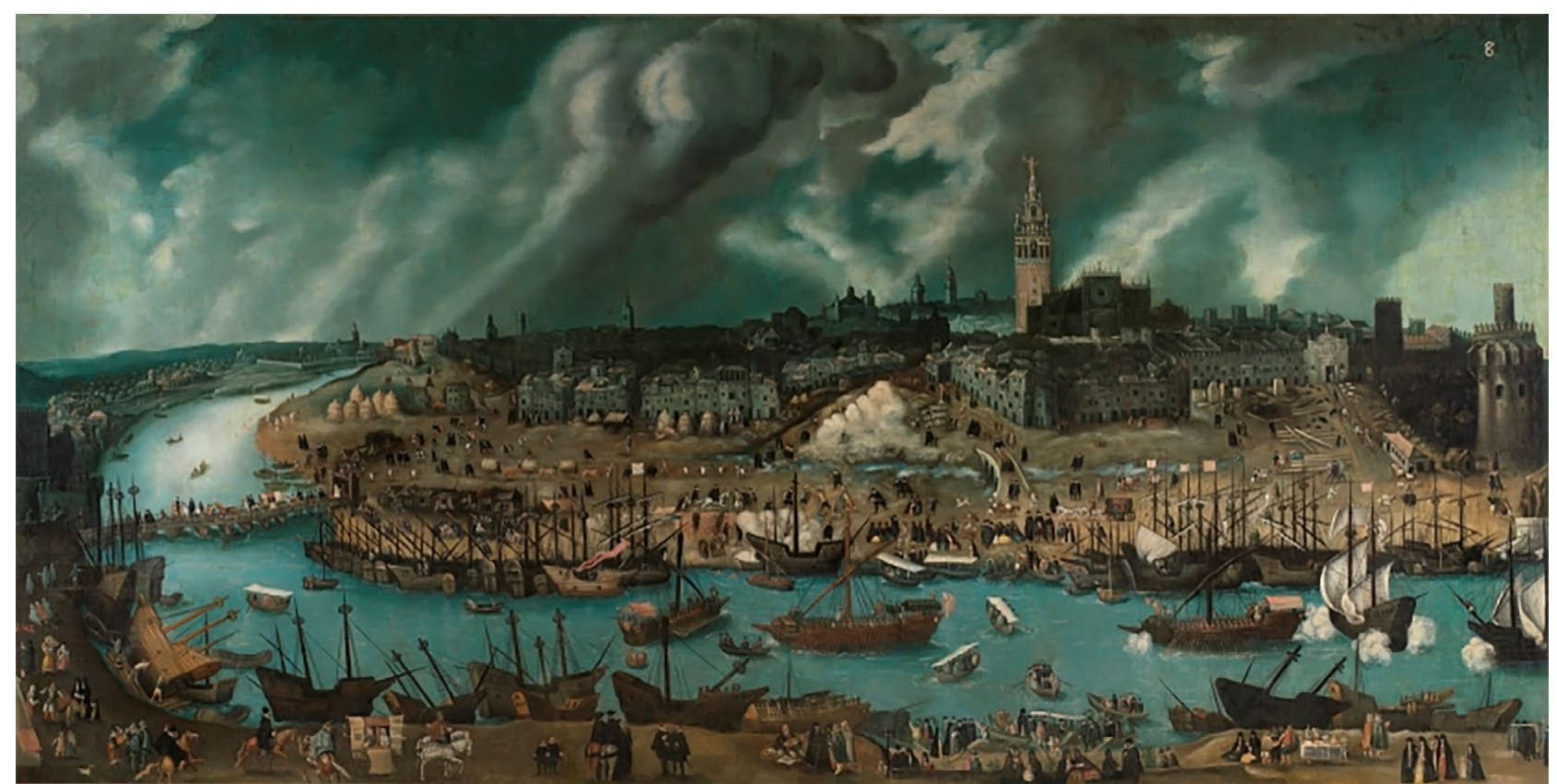

FIGURE 9. View of the city of Seville (anonymous), end of the 16th century. Attributed to Alonso Sánchez Coello. Oil on canvas, 146 x $295 \mathrm{~cm}$. Prado National Museum (Madrid), P004779. 
maravedís paid to Captain Magellan for a spherical plan that he had made for His Majesty (Fernández Navarrete, 1837, pp. 179-180).

The scientific direction of the expedition was left entirely in the hands of the Magellan's trusted men, especially Rui Faleiro, a renowned cosmographer and judicial astrologer who was appointed, together with Magellan, as captain general of the armada. ${ }^{26}$ Faleiro had occupied an important role in the negotiations with Charles I. He had ordered the construction of several charts and other nautical instruments for the expedition and, in addition, had written a Regimiento de la altura de Leste-Oeste (Regiment of the Leste-Oeste height) that have been able to facilitated the calculation of distances during the voyage, especially for Andrés de San Martín, astronomer of the expedition (Castanheda, 1833, pp. 9 and 13; Mota, 1986; Laguarda, 1991). This regiment is one of the most valuable documents of the expedition from the scientific point of view. It explains three procedures to determine longitude, one of the great scientific problems of the Modern Age. ${ }^{27}$ These three methods were through the latitudes of the Moon, through lunar eclipses and through the variation of the compass. ${ }^{28}$

Despite his efforts in the technical direction of the expedition, Rui was unable to embark, as due to some unknown mental illness he lost his mind - "he was almost out of his mind"- and remained in Seville under the care of his brother Francisco. ${ }^{29}$ The mutineer Juan de Cartagena took his place in the captaincy general of the expedition and the scientific work of measurements and astronomical calculations would fall into the hands of the aforementioned San Martín.

Rui Faleiro was, without a doubt, the most important person in the scientific-technical preparations of the expedition. The role of his brother in those preparations, Francisco Faleiro, also a cosmographer, was much more modest. Nevertheless, we know of his participation as technical consultant in several scientific activities of the Casa, like the revision of charts and other nautical instruments, the reform of the Padrón Real or in questions about territorial demarcations. Of Francisco's cosmographic activity in the city of Seville, the publication of his famous Tratado de la esfera y del arte de marear, published in Seville in 1535 , is particularly noteworthy. This is a navigation manual for pilots that would open a new chapter in Iberian treatise - and one could well say, European - on nautical matters. ${ }^{30}$

As far as the young Diogo Ribeiro is concerned, he is usually associated with the production of the nautical charts of the expedition, despite the fact that - as we have seen above - it is Nuño García de Toreno who is referred to in the receipts of the official list of the expenses invested in the Magellan expedition. The little data that is known about García de Toreno seem to indicate that he carried out important cartographic work for the Casa de la Contratación between the years when Amerigo Vespucci was a Pilot Major (1508-1512) and 1526, the date of his death. The last stage of his life, the 1520 s, was one of the most prolific periods of the Casa's cartographic activity. In the opinions gathered in the Junta of pilots and cosmographers of 1515, García de Toreno claimed to have made charts in Vespucci's house (Fernández Duro, 1884, p. 29). He also made charts for the expedition of Jofre García de Loaysa in 1525 together with Diogo Ribeiro (Vigneras, 1962, p. 78). However, he would only receive the post of cartographer at the Casa in September 1519, the same month in which Magellan's expedition left for the Moluccas. Among the many charts that Toreno must have made over a period of almost two decades, only one chart or part of it bears his name, the chart of the Philippines of 1522, which I will discuss later. Two other charts have been attributed to him, the anonymous planisphere of Turin (ca. 1523) - also attributed to Juan Vespucciand the anonymous planisphere of Salviati ( $c a$. 1525).

In addition to Toreno's cartographic work, the expedition required the most advanced cosmographic knowledge and navigation techniques of the period. By 1519, astronomical navigation and nautical charts of latitudes had become part of everyday life in maritime culture. The Greek pilot of the Victoria, Francisco Albo, did nothing else during navigation but take the height of the Sun at midday every day — "with the astronomical instruments that pilots use" (Elcano et al., 2018, p. 147) — as he himself recorded in his logbook, along with other data regarding the course and estimated distance covered. Pigafetta himself refers in his account to latitude coordinates, as well as to the errors of those cosmographers who had never visited the lands through which the expedition passed. Sometimes, he even refers to maps and nautical charts as an element of authority - as when he refers to Martin Behaim's map mentioned above. ${ }^{31}$

Pigafetta's testimony, although scarce, is revealing for two reasons. On the one hand, it gives indications of Magellan's way of navigating, following the parameters of modern navigation..$^{32}$ On the other hand, in criticizing other cosmographers he was doing something even more modern, namely correcting the errors of the old cosmography, of which knowledge was not based on the experience of "seeing with one's own eyes." The young Vincentian was ultimately questioning the authority of ancient knowledge. He expresses this clearly on October 3, 1519 when sailing around the Cape Verde Islands he states: "sometimes we had the wind contrary and at other times sufficiently good, as well as rains without wind. In this manner, we navigated with rain for the space of sixty days until the equinoctial line, which was a thing very strange and unaccustomed to be seen, according to the saying of some old men and those who had navigated here several times" (Pigafetta, 2019, p. 41). The ancients considered that it did not rain in the tropics and that it was an uninhabited region of the world.

Transylvanus' letter also insists on criticism of the ancients: "For whatever we read concerning the native soil of the spices has been told to us by ancient authors, and is partly, certainly, fabulous; and, partly, so far from the truth" (Stanley, 2010, p. 184). Both, Pigafetta and Transylvanus, give an account of the new natural and cul- 
tural world that the expedition found in the way of modern naturalists and ethnographers, overcoming the limits of ancient knowledge in this field, too.

\section{Magellan's voyage: the Strait and the Moluccas $^{33}$}

On September 20, 1519, the expedition led by Magellan set sail from Sanlúcar de Barrameda with 239 men of different nationalities ${ }^{34}$ aboard five galleons, the San Antonio, the Trinidad (the captain's ship), the Concepción, the Victoria (the only one that survived) and the Santiago. ${ }^{35}$ After passing through the Canary Islands and the coast of Guinea - the usual itinerary for the fleets of the Indies - the five ships crossed the Atlantic and reached American lands in a period of almost three months. By mid-December, they were in Rio de Janeiro (Brazil) and at the end of the same month in the Rio de la Plata (Uruguay and Argentina). The adverse weather conditions and the inclemency of the cold winter forced the expedition to stop their journey at the port of San Julián (Argentina) between March 31 and August 24, 1520. During this time, several remarkable events took place. The Santiago was shipwrecked in May, and the first mutiny of the armada against Magellan, led by Juan de Cartagena, would take place there. The difficult situation would be solved with an iron hand by the Portuguese captain. Meanwhile, the harshness of the voyage began to take its toll, whether through disobedience, illness, or voluntary deprivation of life. According to Pigafetta, at the end of August they arrived at the Santa Cruz River and at the end of October at the Eleven Thousand Virgins, after which there was the longed-for strait, the maritime passage to the South Sea. Magellan had achieved the first objective of the expedition after a year of inclement weather.

Throughout the month of November the armada crossed the strait, called the "Strait of All Saints"; not before having lost another of the ships, the San Antonio, which deserted and returned to Seville after another mutiny led by Esteban Gomes. ${ }^{36}$ On November 28th, they left the beautiful strait behind and entered the Pacific Ocean heading northwest, heading with perseverance towards their second objective, the Moluccas, located at a latitude close to the equator (Medina, 1920). ${ }^{37}$ The unprecedented voyage through the calm ("pacific") waters of the new ocean took more than three months without seeing any land, except for two uninhabited islands - the Unfortunate Islands - and the famous Magellanic Clouds - two large galaxies visible from the southern hemispherewhich Pigafetta considered "not very large, nor very brilliant" (Stanley, 2010, p. 66). ${ }^{38}$ During those fateful weeks, hunger was increasingly present and the dreaded scurvy had befallen several crewmembers. Tempers would be raised by the arrival of the Islands of the Thieves (Mariana Islands) in the Far East in early March 1521. In the middle of the same month, they arrived at the archipelago of San Lazaro (Philippine islands) where Magellan established friendly relations with the local rulers of Butuan and Cebu, and where gold was found and several inhabitants of those lands were baptized in the Christian faith.
Meanwhile, deaths and desertions continued. On May 27 th, the voyage would end for Magellan, who died in a stupid battle in front of hundreds of natives of the Island of Mactan and their leader Lapulapu, an act that as some historians have suggested was deliberately suicidal. The captain had died without achieving his purpose.

\section{Elcanos' voyage: the circumnavigation}

Other expeditioners died or were captured in Cebu, where the local king had set a trap for them. Among them was the astrologer Andrés de San Martín. The survivors who managed to escape left for the Island of Bohol, now captained by Juan Carvalho. There, given the scarcity of the crew, they decided to burn one of the three ships they had left, the Conception. They continued on to Borneo, where they arrived in June 1521 after passing through Mindanao. They invested several weeks in the surroundings of that place, repairing the battered ships, sailing through its narrow waters, and looking for the islands of spices. By this time, Juan Sebastian Elcano had taken command of the expedition. Finally, on November 8, they arrived at Tidore, where ruled the Muslim King al-Mansur, an "excellent astronomer" - according to Pigafetta. After more than two years of hard navigation, they had reached the great goal, the five islands of the Moluccas: Ternate, Tidor, Moti, Makian and Bacan, full of clove and inhabited by Malays converted to Islam. They were there until December 21, when the Victory departed back for Spain, sailing westward loaded with cloves and leaving the damaged Trinidad anchored there.

Once repaired, the crew of the Trinidad, commanded by Gonzalo Gómez de Espinosa, decided to return to Spain on the opposite side, sailing northeast with the intention of reaching Panama, a route that would later be discovered by the Augustinian Andrés de Urdaneta - the route of the Manila Galleon. Without success and after months of hard and painful navigation they returned to the Moluccas, where they were captured and imprisoned by the Portuguese captain and governor Antonio de Brito and his men. ${ }^{39}$ From there, they would go to Lisbon after passing through India and finally, thanks to the intercession of Charles I, to Castile, where they would be interrogated. ${ }^{40}$

On its return to Seville, the Victoria passed through several islands and places in Southeast Asia while trying to avoid approaching places under Portuguese rule, such as Malacca and Sumatra. Pigafetta described the richness and customs of these places. On February 11th, they entered the Indian Ocean in a southern direction in search of the Cape of Good Hope, which they managed to turn on May 6th. Again, food was scarce, and death visited more than twenty men, whose bodies were thrown overboard. On July 9th, they arrived at the island of Santiago, in Cape Verde, where they discovered to their surprise that it was Thursday (July 10th) and not Wednesday. They had lost twenty-four hours as a result of having returned to the starting point by always sailing westwards, that is, following the opposite direction to the movement of the Earth's axis of rotation. ${ }^{41}$ Thirteen men were also captured 
there by the Portuguese. Two months later, on September 6,1522 , the Victoria entered Sanlúcar, the place that saw it set sail, with 18 survivors - of the 60 who left the Moluccas - almost all of them sick. ${ }^{42}$ The ship captained by Elcano had sailed around the world.

Almost three years and 14,460 leagues later only a small group of sailors returned to the peninsula. The survivors were welcomed as heroes and rewarded by the king. Not, of course, before hearing in person, what Elcano and two other survivors -Francisco Albo and the barber Fernando de Bustamante - had to tell him about the voyage. ${ }^{43}$ They were given money, but also coats of arms representing cloves and nutmeg; and an image of the world with an inscription that said primus qui circumdedisti me (the first to circumnavigate me) (Santa Cruz, 1920-1923, p. 22). ${ }^{44}$ Charles I rewarded them both for the commercial impact of what they had done and for the scientific feat they had accomplished, they had gone around the universo orbe - in the words of Transylvanus - always sailing from east to west. ${ }^{45}$ Is this not a sufficient sign of scientific modernity? In the words of the Spanish Jesuit José de Acosta, "who is he then that will not confess by this Navigation [the ship Victoria] but the whole earth (although it were bigger then it is described) is subject to the feet of man, seeing he may measure it?" (Acosta, 1880, p. 5).

\section{AFTER THE VOYAGE: A GLOBAL IMAGE OF THE WORLD}

In addition to the accounts mentioned so far, the geographical results of the expedition were partly collected by Nuño García de Toreno in a chart of the Far East dated 1522. This chart was made in the "noble town of Valladolid" - where the court was located and where Toreno apparently used the information provided by Juan Sebastián Elcano to King Charles I (Fig. 10). This chart is, together with the so-called anonymous chart of Istanbul in polar projection, and a chart of the Indian Ocean, both attributed to Pedro Reinel, the first cartographic testimony made with sources from the expedition (Magnaghi, 1927). The chart of Toreno, which seems to be part of a lost planisphere, represents South and Southeast Asia, the Indian Ocean and some of its imaginary islands, the Malacca Peninsula and the archipelago of the coveted Moluccas Islands, located to the east of the antimeridian, in the area of Castilian influence. The red demarcation line stands out, cutting in half the Indochinese Peninsula and the island of Sumatra, under which it can be read: Linea divisionis castellanorum et portugalliensium (line of division between Spanish and Portuguese). ${ }^{46}$

The chart of the Moluccas is a chart of latitudes made with the geographical data of the expedition that fed the diplomatic confrontation between Portugal and Castile in their particular race towards the spices. It is a chart of political vindication built at one of the highest moments of diplomatic tension between the two powers. If, as has been maintained, this chart was given by Charles I to his sister-in-law Beatrice de Portugal, of the Avís dynasty and

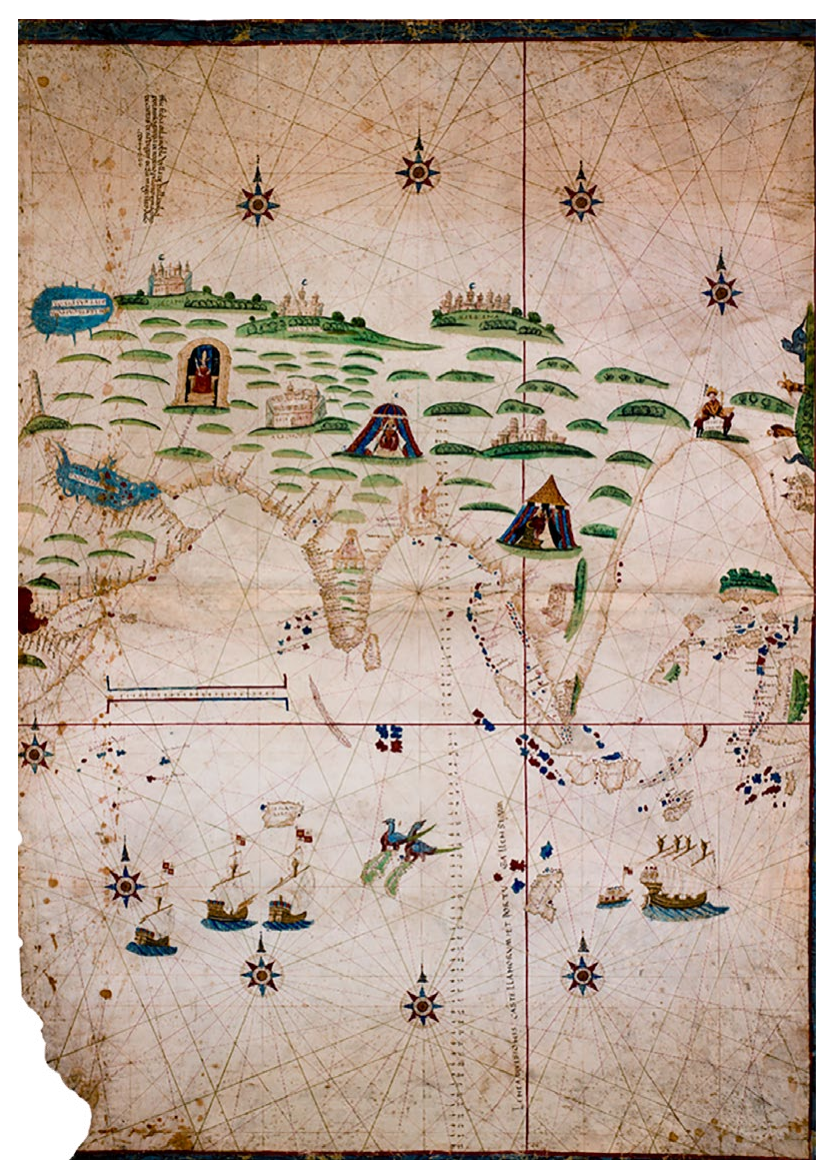

FiguRE IO. Nautical chart of the Indian Ocean and the Moluccas including the antimeridian of Tordesillas, Nuño García de Toreno, 1522. Royal Library of Turin, Coll. O XVI/2. Manuscript on parchment, $108 \times 75 \mathrm{~cm}$

married to Charles III of Savoy, its vindictive meaning would have to be added to a propagandistic intention of notable interest (Martín-Merás, 1993, p. 87). The king and his ambassadors used some of the charts made by the cartographers of the monarchy as poisoned gifts, where the courteous and distinguished gesture of giving a gift implied obtaining recognition. The receiver could only interpret this gesture as evidence of affirmation. Several of the great Spanish nautical planispheres of the $1520 \mathrm{~s}-$ presumably copies of the Padrón Real- had this purpose.

For its part, the so-called anonymous chart of Magellan - also known as "Hazine 1825" - attributed to Pedro Reinel ( $c a$. 1522) was drawn on a polar projection representing the southern hemisphere (Fig. 11). The northern hemisphere must have been represented in another (lost) half of the chart. In the chart, South America can be seen as far as the Strait of Magellan. As in the anonymous planisphere of Munich, the equinoctial line appears graduated in intervals of five degrees, as is graduated the meridian of partition cutting the entire south hemisphere to leave the Moluccas of the Portuguese side (Destombes, 1955; Cortesão and Mota, 1987, I, pp. 39-41; and Couto, 2013). ${ }^{47}$ The chart of the Indian Ocean attributed to Pedro Reinel also made around 1522 represents the Moluccas 
Making a Global Image of the World: Science, Cosmography and Navigation in Times of the First Circumnavigation of Earth, 1492-1522 • 15

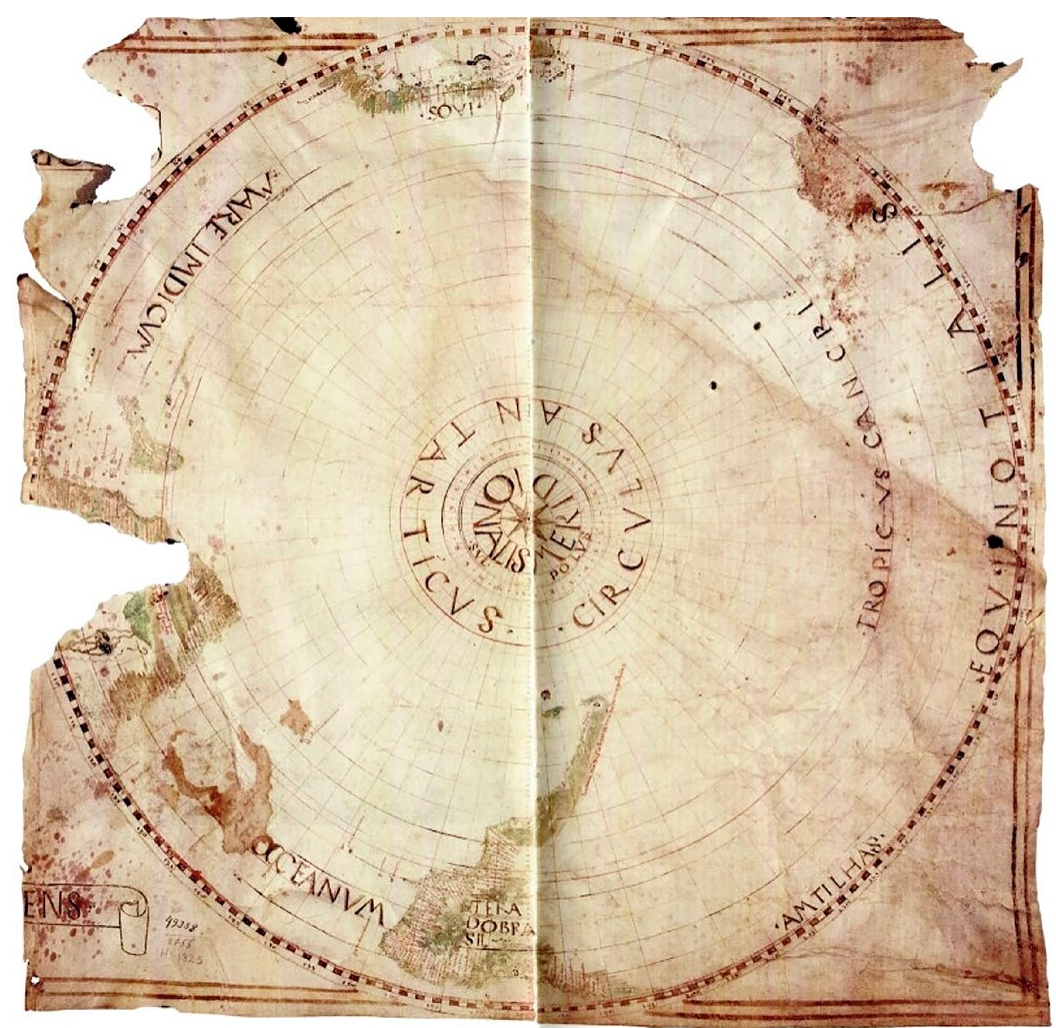

FIgURE I I. Polar map of the southern hemisphere representing the Moluccas on the Portuguese side. [Pedro Reinel], ca. 1522. Topkapi Sarayi Müzesi, Istanbul (Turkey). Manuscript on parchment, 68.2 x $70 \mathrm{~cm}$.

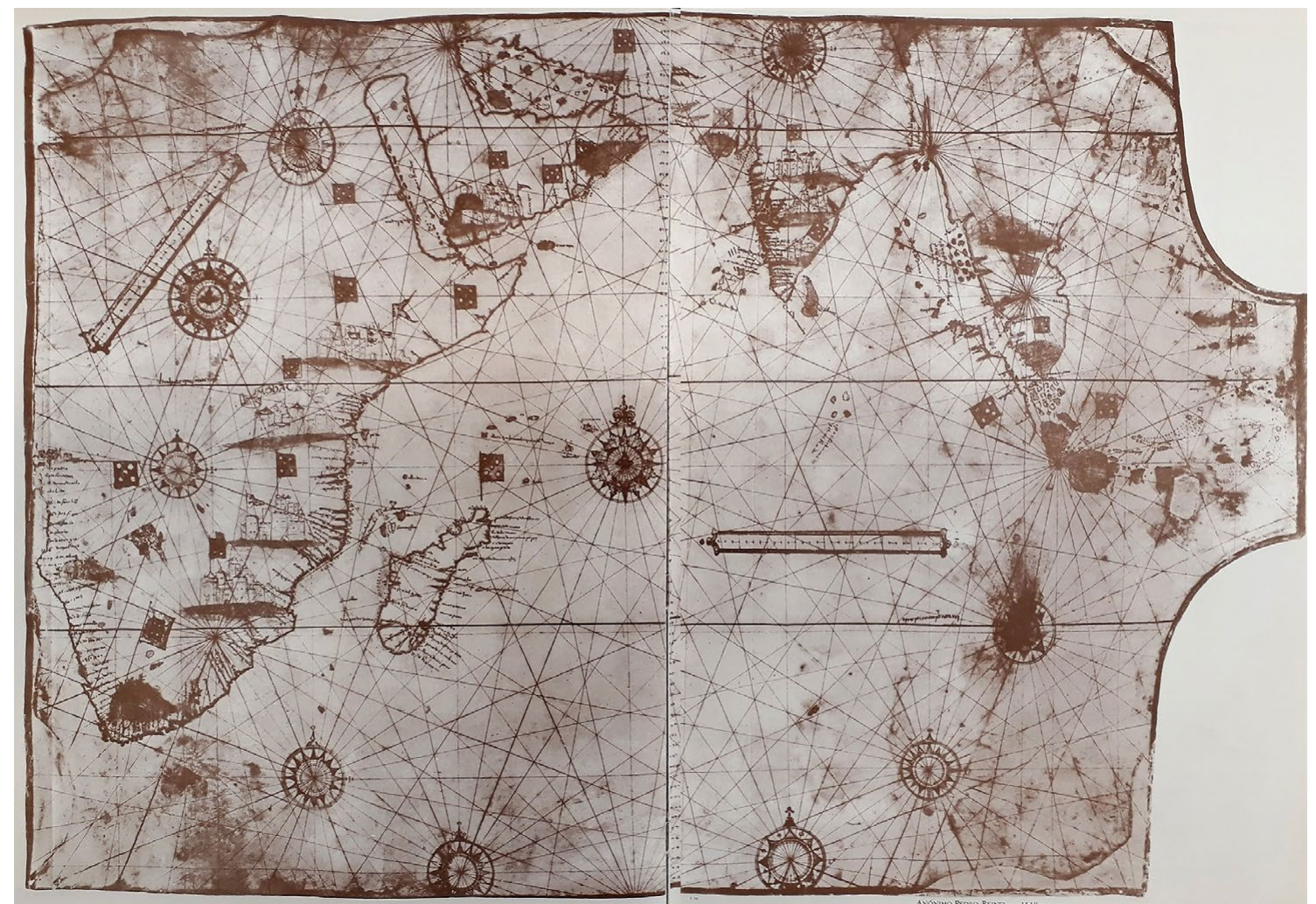

Figure I2. Chart of the Indian Ocean and the Moluccas, represented on the Portuguese side [Pedro Reinel], ca. 1522. British Library, London (United Kingdom). Add. MS 9812. Manuscript on parchment, 103 x $69.8 \mathrm{~cm}$. 
on the Portuguese side (Cortesão and Mota, 1987, I, pp. 35-36) (Fig. 12).

The arrival of the Victoria in Seville with new information and new testimonies must have exceeded the expectations of the Casa's cosmographers in charge of the Padrón Real, which had to be urgently updated. After the first voyage around the globe, the image of the world had changed considerably - both in its physical aspect and in its political significance - and required to be re-mapped.

The charts of Reinel and García de Toreno were followed by the anonymous Turin planisphere of 1523 , a new cartographic work built with the information collected by the expedition (Fig. 13). It is the first universal chart that incorporates such information. It has been attributed to García de Toreno, but also to Juan Vespucci, since both had license of the king to carry out cartographic works, one as cartographer and the other as someone authorized to make copies of the Padrón Real (AGI, Indiferente, 418, L.3, ff. 324v-325v).

The Turin chart represents Europe, Africa, Asia to the Indochinese Peninsula, the Antilles, and the Atlantic coast of America from the Gulf of Mexico and Florida to the Strait of Magellan. ${ }^{48}$ The Moluccas, represented on the far left, are located to the east of the imaginary antimeridian, on the Castilian side. Its location on the left side of the chart shows a clear political vindication that will be repeated in all the planispheres of the Casa. However, the meridian was not traced in the Turin chart. Instead, what appears to be the antemeridian was delineated, even though it leaves Malacca outside Castilian jurisdiction. The author claims to be aware of some of the latest explorations of the New World, but ignores many others. One of the great novelties is the representation of the Strait of Magellan, which opens up the possibility of exploring the South Sea towards the East Indies. This will be the first in a series of planispheres made by the Casa's cartographers during the $1520 \mathrm{~s}$, a prodigious decade. The cartography of that period would reflect several of the most important events that took place in the Iberian Peninsula during that decade, from the Junta de Badajoz-Elvas of 1524 to the Treaty of Zaragoza of 1529, including the marriage of King Charles I with Isabel of Portugal in $1526 .{ }^{49}$

The end of the voyage brought the Moluccas' dispute to a head, causing the resurgence of the debate on the demarcation line and calling more than ever for a new map. The chart of García de Toreno constituted a good tool of defense and an extraordinary example of propaganda to reaffirm the rights of Castile before the Courts, since it represented the Moluccas islands in the Castilian side. The maps were in this occasion political artefacts imbued with scientific authority. As it has been already said, this was the first Spanish map of the region of the south and Southeast Asia where the antimeridian of the Moluccas appeared drawn.

Likewise, in 1523 the first account of the voyage would be published, the De Moluccis Insulis by Maximilianus Transylvanus, secretary to the emperor and brotherin-law of Christopher of Haro, one of the main financial promoters of the expedition. However, the greatest narrative glory of the event would go to the Venetian Antonio Pigafetta and his Relazione del primo viaggio intorno al mondo, published the following year, which with its dramatic and realistic prose became the main testimony of the expedition. Unlike Pigafetta's story, Transylvanus' letter narrates the experience of the voyage through the testimony of the survivors.

The stories of Transylvanus and Pigafetta did not reduce the tension, but they did serve as an incentive to end a dispute that had advanced very little since Tordesillas, and that seemed to have no end. In 1524, the Junta of Badajoz-Elvas were held with the aim of closing the dispute. As with almost all the meetings held in this context, expert cosmographers and navigators led them. In these meetings, what is likely to have been used is the world

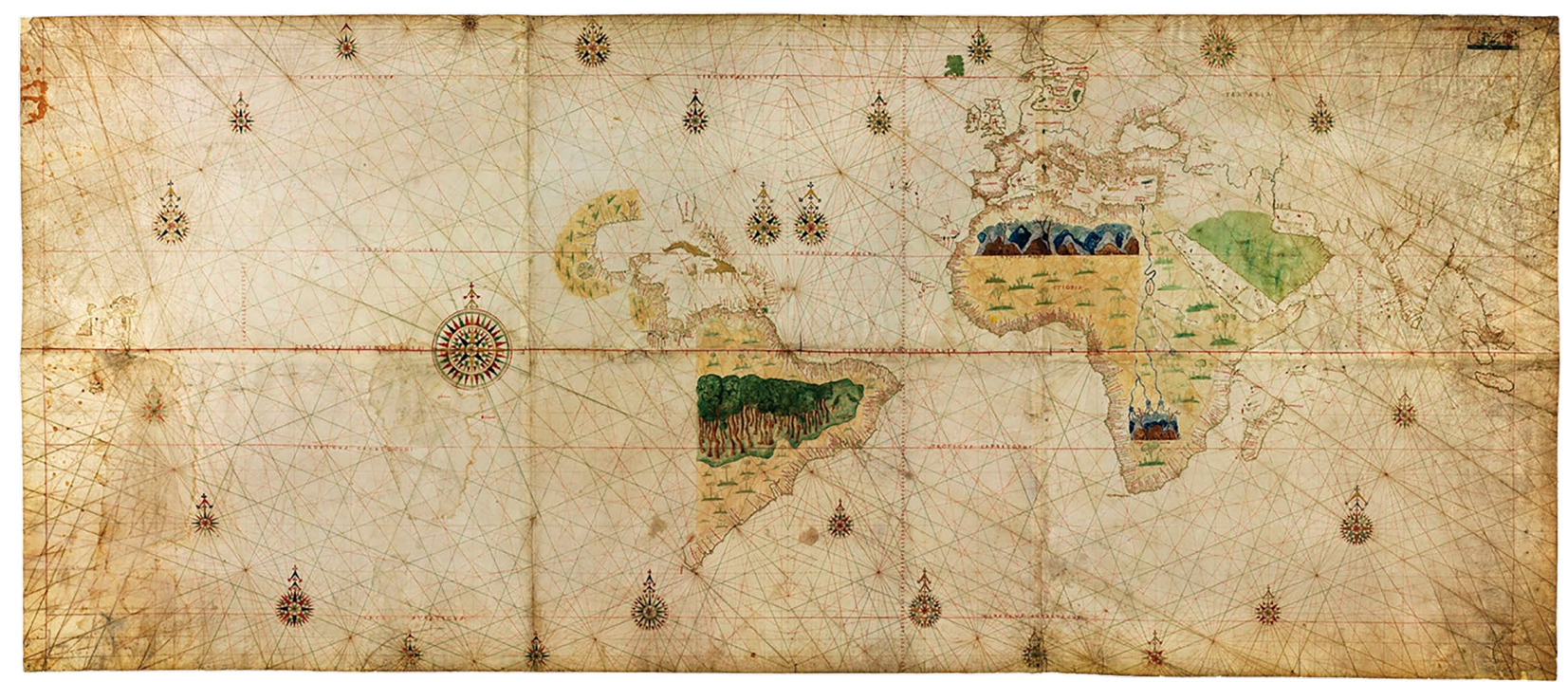

FIGURE I3. Anonymous planisphere of Turin representing the Moluccas on the Spanish side, $c a .1523$ [Nuño García de Toreno/Juan Vespucci]. Royal Library of Turin, Coll. O. XVI.1. Manuscript on parchment, 112 x $262 \mathrm{~cm}$. 


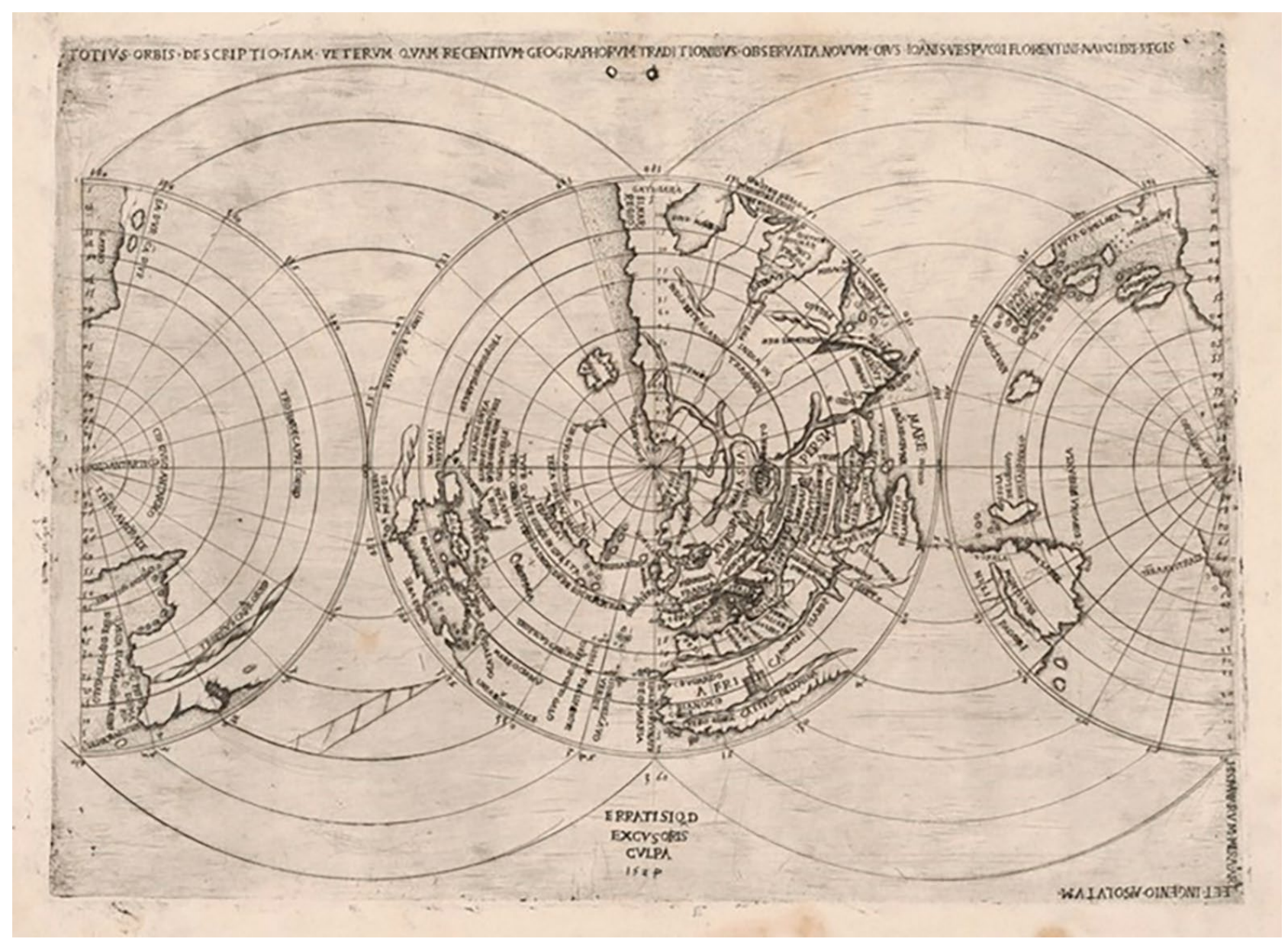

FIGURE I4. Juan Vespucci's world map Totius orbis descriptio tam veterum quam recentium geographorum representing the meridian and antemeridian of Tordesillas, 1524. Houghton Library, Harvard University, p 51-2573.

map of Juan Vespucci of the same year, which represents the meridian and the antimeridian of Tordesillas (López de Gómara, 1979, p. 57) (Fig. 14). In the case of the Moluccas, their role was to guide the king and seek the most persuasive scientific explanation in order to win the rights to the spice trade. Three central issues were raised at these meetings: what would be the best cartographic medium on which to represent the line of demarcation, a nautical chart or a globe; how to situate the islands of Cape Verde on this mapping device; and from which point among of these islands to start the 370-league count. Nevertheless, these points highlight the few agreements that the Spanish and Portuguese had been able to reach during the thirty years following the Treaty of Tordesillas. The scientific debate was irremediably linked to the problem of determining longitude, a problem that scientific modernity would still take some time to solve. However, the points of view could not have been more opposed. If the Spaniards accused the Portuguese of altering distances and misreading charts, the Castilian cosmographers traced the antimeridian through Malacca. After two months of meetings, the negotiations failed again in their attempt to find a point of understanding, which would only come about five years later. Meanwhile, Charles I did not stop trying to reach the Moluccas by other means of access. Esteban Gómez tried in 1523, Jorge García de Loaysa in 1525, and Sebastian Cabot in 1526, all without success.

If Columbus' first voyage resulted in the Treaty of Tordesillas, the circumnavigation of Magellan-Elcano led to the Treaty of Zaragoza, signed on 22 April 1529 (AGI, Patronato, 49, R. 9). At that time, Charles I was immersed in Spanish-Portuguese matrimonial policy and a European war, as well as with the diplomatic and economic exhaustion that both problems generated. This agreement was presented as a viable way out for both Portugal and Castile. King John III presented Charles I with a tempting offer for the lease of the Moluccas. In the meantime, the famous Vatican planisphere of Diogo Ribeiro of 1529 placed the Moluccas 172.5 degrees west of the line of separation of Tordesillas, on the Castilian side, like all the charts of the Casa of that period (Sánchez, 2013, pp. 177-210) (Fig. 15). However, with the agreement of Zaragoza, Charles I renounced the islands and ceded his rights of exploitation to the Portu- 


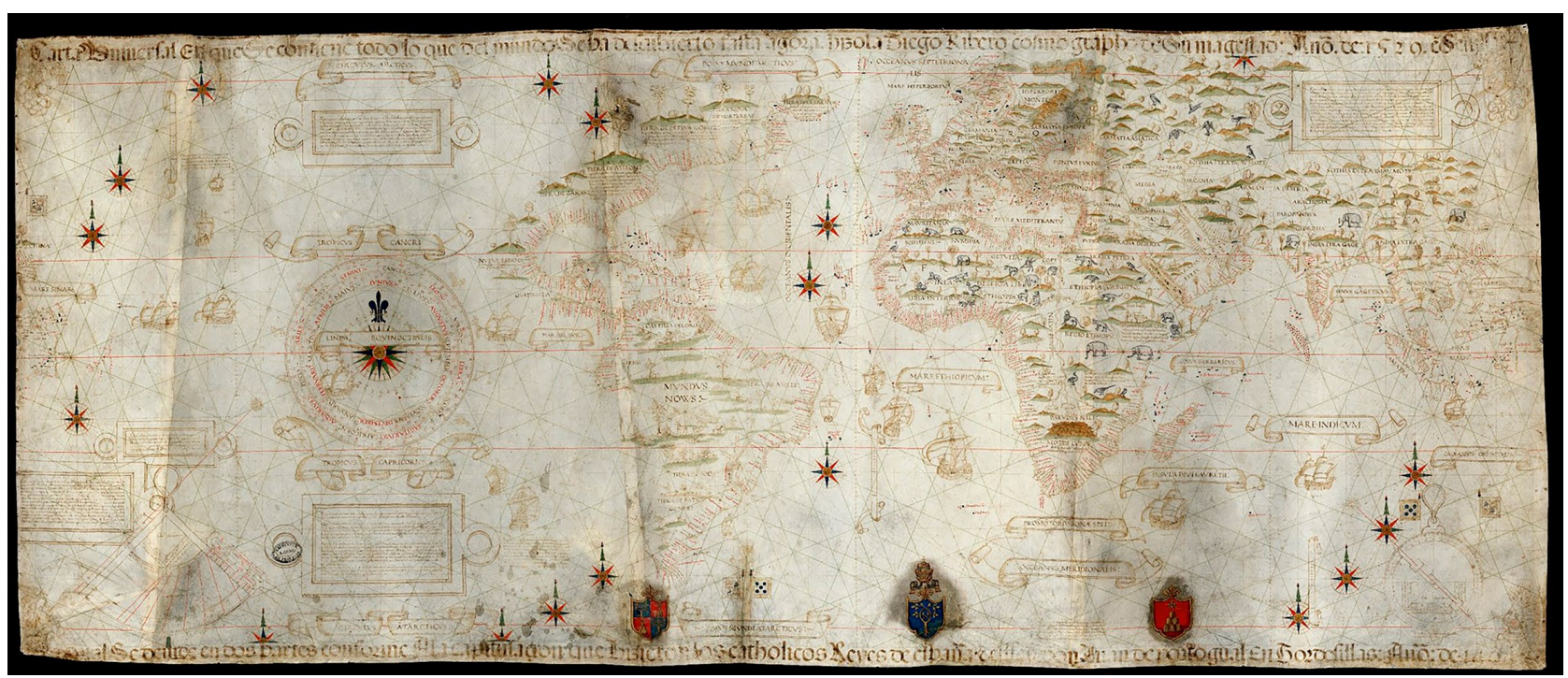

FigURE I 5. Nautical planisphere of Diogo Ribeiro representing the Moluccas on the Spanish side, 1529. Vatican Library, Borg.Carte. naut.III. Manuscript on parchment, $204.5 \times 85 \mathrm{~cm}$.

guese crown for the price of 350,000 gold ducats or, in other words, 131,250,000 maravedís. Thus, despite its significant economic consequences, the diplomatic battle between Portugal and Spain was not only fought on land but also at sea; it was a nautical and cosmographic conflict.

In addition to the Ribeiro planisphere, other Portuguese and Spanish maps of the Moluccas followed the Zaragoza agreement. In 1566, the new monarch, Philip II, reopened the debate asking Fray Andrés de Urdaneta and the cosmographers Alonso de Santa Cruz, Pedro de Medina, Francisco Faleiro, Jerónimo de Chaves and Sancho Gutiérrez to give their opinion about the position that the Philippines occupied in relation to the agreement of Zaragoza. The experts' opinion placed the Moluccas back on the Castilian side, which meant that the spices would continue to be exploited by Portugal, as stipulated in the treaty of 1529. The Philippines would torment Philip II even after the union of crowns in 1580. In 1611, the Portuguese cosmographer João Baptista Lavanha concluded that the Moluccas were more than three degrees within the boundaries of Portugal, a calculation close to the nearly five that they actually were. Lavanha's verdict and the arrival of the Dutch East India Company on the Moluccas in the early 17 th century placed Spain and Portugal further away from the coveted Spice Islands, and further away from modern science.

The impact of the voyage was felt inside and outside the Iberian Peninsula, especially from the second half of the 16th century onwards. The expedition initiated by Magellan and completed by Elcano would modify the cartographic image of the world and, consequently, the geographical thinking of modern Europe (Heawood, 1921). The new global image of the world was reflected in the famous planispheres of Diogo Ribeiro in the second half of the $1520 \mathrm{~s}$, but its echoes also reached the workshops of renowned cartographers such as Abraham Ortelius,
Giovanni Battista Ramusio and Battista Agnese. In short, as Stefan Zweig states in such a revealing and elegant way, a new time had begun. To which this article would add, that a new time had also begun in our scientific understanding of the planet.

Meanwhile the news of the fortunate return of the eighteen spread like wildfire across Europe, rousing immeasurable astonishment and admiration. Since the voyage of Columbus, no event had so stirred the contemporary world. Uncertainty had been put to rest for ever. Doubt, the fiercest foe of human knowledge, had been vanquished in the geographical field. Since a ship had set sail from the port of Seville, and, sailing, continually westward, had returned to the port of Seville, it had been irrefutably proved that the earth was a globe surrounded by a continuous ocean. At length the cosmography of the Hellenes and the Romans had been transcended, in defiance of the veto of the Church and foolish fables concerning the men of the Antipodes who must walk upon their heads. Established once and for all had been the circumference of the earth, the measure of the cosmos. Other bold discoverers could and would fill in numerous details in the world-picture, but the basic form of our planet had been ascertained by Magellan, and persists for all time to come. The world was a restricted region which man had conquered. This day, famous in history, had firmly established the pride of the Spanish nation. Under the flag of Spain, Columbus began the work of modern discovery, and under the same flag Magellan completed it. Thirty years had taught more about the place of man's habitation than had thousands and thousands of years before. Though half unwittingly, the generation which had had this intoxicating, this stupendous experience, realized that a new age, the modern age, had begun (Zweig, 2016, chap. 13). 


\section{CONCLUSIONS}

Indeed, a new time had begun. Why not a new science? Was not it, as Zweig reminds us, the empirical demonstration of the Earth's sphericity - which also revolves around itself-, the verification of the dimensions of America and the Pacific, and the discovery of a passage connecting two great oceans sufficient reason to inaugurate a new scientific era? Was not the measurement of our planet's orbit, the overcoming of the cosmography of the ancients, and the voyage around the world enough? Were not these achievements modern enough?

This article argues that yes, these were more than enough reasons. That is why the celebrations and collective memories of the fifth centenary of Magellan-Elcano's voyage are a good opportunity to do historical therapy and to revive this voyage in the face of a major problem, the genesis of modern science and European scientific modernity. Beyond sterile debates about whether the merit of the first circumnavigation belonged to the Portuguese or the Spanish, the commemorative atmosphere we are experiencing is presented as a good opportunity not to celebrate the history of Iberian civilization, but rather to critically rethink what role this and other events occupy in the global framework of the modern era.

In this article, I have reconstructed the political motivations, the institutional framework and the technical-scientific developments that allowed the materialization of Magellan's voyage in 1519. In doing so, I have argued that the Magellan-Elcano expedition was a voyage of science with a scientific objective that led to another scientific fact - probably unsuspected, but of greater dimensions - the first voyage around the world. The question is: was this voyage a mere Iberian adventure or rather the manifestation of a type of science that illustrates a whole era? Why does it still occupy a marginal role in the narratives about the emergence of modern science? Why has such an innovation been relegated only to the world of voyages of discovery and techniques? From now on, the new object of study of modern science will be the orb, the globe, everything that exists. In short, the aim of modern science would be to offer a greater understanding of the place in which we live.

\section{ACKNOWLEDGEMENTS}

I express here my gratitude to the anonymous referees of this article for their comments and suggestions that have undoubtedly contributed to its improvement. I would also like to thank Billy Falvey for his invaluable help with the English version of this article. The research leading to this work was partially supported by the European Research Council (ERC) under the European Union's Horizon 2020 Research and Innovation programme (RUTTER AdG, grant agreement No. 833438); as well as the project "Iberian Maritime Culture and Oceanographic Practices in the Mediterranean and the Atlantic: tacit knowledge, standardization, practical knowledge and geopolitics" (PID2019-111054GB-I00) supported by the Ministry of Science and Innovation of the Spanish Government.

\section{NOTES}

1 Initially intended to last two years

2 Most of the maps that are included in this article have been majestically reproduced in Moreno Martín (2019a). On the maps from the voyage, see also (Manso, 2019a; Moreno Martín, 2019b; Castro, Hamon and Thomaz, 2007).

3 In the "Discorso sopra il viaggio fatto da gli Spagnouli intorno al mondo" which precedes the publication in Italian of Transylvanus famous letter on the Moluccas, Ramusio stated that Magellan-Elcano's expedition was: "one of the greatest and most remarkable that there has ever been, and one at which those great philosophers of old, hearing of it, would have been stupified and beside themselves." Stanley (2010, p. 182). D'Anghiera also praised the feat and alluded to the Greeks: "What is most strange, and what had never before been attempted since the beginning of the world, is that this ship followed the entire parallel and made the circuit of the globe. If a Greek had accomplished this what would not the Greeks have written about his incredible feat!" Anghiera (1912, p. 166). The same spirit led Pedro de Medina to write the following words in chapter XXV of his Libro de las grandezas y cosas memorables de España: "This is such a great thing [to go around the world] that after God created the world, it was never done, nor thought, nor even believed to be possible." Medina (1549, f. 28r). Author's translation. In spite of his praise, Medina incurs later (chapter 49) in a series of inaccuracies about Magellan's expedition. Likewise, in chapter I of book XX of the second part of the Historia general y natural de las Indias, Fernández de Oviedo praises the feat of the ship Victoria affirming that it was the "first and only that sailed the whole globe [...]. The truth of the thing is that there is not known nor written, nor another similar seen, nor one so famous in the world." Fernández de Oviedo (1852, p. 21).

4 For a historiographic review of Magellan and the expedition, see Torodash $(1971,1995)$.

5 See the classic works on modern science and the Scientific Revolution by Butterfield (1949) and Koyré (1962), as well as the more recent works by Shapin (1996) and Dear (2001).

6 Extract from Una casa en la arena (1956-1966) by Pablo Neruda. Cited in Serrera (2019, p. 324).

7 In this article, I will follow the English version of the sources of the expedition found in Stanley (2010), with the exception of the Ginés de Mafra's narrative and some letters. See Elcano et al. (2018).

8 Turnbull was referring to the Armazéns da Guiné e Índia (Wharehouse of Guinea and India), which was the institution where the cartographic activities of the Portuguese Crown were concentrated.

9 Isabel Soler has highlighted the value of great voyages of discovery, such as Magellan's, for the birth of the modern world (Soler, 2015). In this sense, Soler recovers - free of over-blown patriotism - the homage that Oliveira Martins made to the Iberian civilization in the context of modern European history (Martins, 1879). An argument that has been continued more recently by Fernández-Armesto (2010) or Insua (2019, pp. 93 and 170), among others.

10 About the Treaty of Alcaçovas-Toledo, see Varela Marcos (1996, pp. 109-111), Rumeu de Armas (1992, pp. 263-265), and Castañeda (1973, pp. 103-115). On the Portuguese-Spanish rivalries before the Treaty of Tordesillas, see Pérez Embid (1948). See also Hampe Martínez (1999).

11 On Columbus and the Court's demands for the construction of a map showing the new discoveries, see Fernández Navarrete (1853), Colón (1986), and Varela (1988).

12 The second of the four Alexandrian bulls, the Inter Caetera bull granted on 4 May 1493 by Alexander VI to the Catholic Monarchs, legitimised the ownership of the new territories. The new text conferred on Castile, by apostolic authority, the donation, constitution, and allocation of: "all islands and mainlands found and to be found, discovered and to be discovered towards the west and south, by drawing and estab- 
lishing a line from the Arctic pole, namely the north, to the Antarctic pole, namely the south, no matter whether the said mainlands and islands are found and to be found in the direction of India or towards any other quarter, the said line to be distant one hundred leagues towards the west and south from any of the islands commonly known as the Azores and Cape Verde. With this proviso however that none of the islands and mainlands, found and to be found, discovered and to be discovered, beyond that said line towards the west and south, be in the actual possession of any Christian king or prince" (Remesal, 1994, p. 135). Thus, the first bull proclaimed the sovereignty of Castile and the second defined the areas over which it could exercise that sovereign power. On the 26th of September 1493, Alexander VI granted Ferdinand and Isabella the bull Dudum siquidem, the fourth and last of the Alexandrian bulls, which extended the donation to Castile of all those Asian territories that were discovered from the West. See Gutiérrez Escudero (1990, pp. 130-132). The logical disagreement of John II would become apparent the following year in Tordesillas.

13 For the historical process that took place between Columbus' discovery and the signing of the Treaty of Tordesillas, see Sánchez (2009, pp. 3-6).

14 For Alexandrian Bulls, see also Linden (1916), Pino Ycaza (1945), and Rumeu de Armas (1992, pp. 268-269). On the geographical and political implications of the Tordesillas meridian, see Manzano (1942), Pérez de Tudela (1985), Cerezo Martínez (1994b); and Trueba and Llavador (1997).

15 In the document, the King of Portugal asked the Kings of Castile "that a boundary or straight line be determined and drawn north and south, from pole to pole, on the said ocean sea, from the Arctic to the Antarctic pole. This boundary or line shall be drawn straight, as aforesaid, at a distance of three hundred and seventy leagues west of the Cape Verde Islands." Archivo General de Indias (AGI), Patronato Real, 1, N. 6. R. 1. See also Tratado de Tordesillas (1973, p. 58) and Fonseca and Ruiz Asencio (1995). On the other seven points of the agreement, see Tratado de Tordesillas (1973, pp. 55-61).

16 "As yet, nothing of the longitude had been clearly proved" (Stanley, 2010, p. 187).

17 Although a little exaggerated, the testimony of the Spanish cosmographer Andrés García de Céspedes is revealing. In 1606, he lamented the difficulties [Spanish cartographers] have had in representing "the coasts of the Mar Océano (Atlantic)", due to the deliberate efforts of the Portuguese to "obscure" information about the colonies on their maps. According to Céspedes, the Portuguese had made maps "shortening" in their "descriptions the coast of Brazil all the way down to the island of Gilolo, walking on the eastern side." Not content with that, they had "dispersed these maps all over Europe" making known to foreigners an unreal world (García de Céspedes, 1606, p. 128).

18 Luís de Camões would remember this act of disloyalty in the 140th octave of the tenth canto of Os Lusiadas: "Magellan was truly a Portuguese in reality, but not in loyalty" (Camões, 1819, pp. 369). The idea of betrayal is also present in Chapter 6 of Book VI of Castanheda (1833, pp. 8-9).

19 "The course they say they are taking is from Sanlúcar straight for Cabo Frío, leaving Brazil to the right until they pass the dividing line. And from there sailing west and northwest [right] to Maluco, whose land I saw represented in the poma and chart that Reinel's son made here, which was not finished when his father came for him. His father then finished everything and put in these lands of Maluco. All the charts that Diogo Ribeiro makes are made from this pattern chart, as well as the compass, quadrants and spheres" (Fernández Navarrete, 1837, p. 155).

20 Colour facsimile edition made in 1843 by a Bavarian officer named Otto Progel. The original was kept at the Bayerische Armeebibliothek in Munich until it disappeared at the end of World War II (Sánchez, 2013, pp. 172-174).

21 There is an extensive bibliography on the so-called "Moluccas dispute." See, among others, Denucé (1908-1911), Latorre (1923), Hidalgo Nieto (1942), Branquinho (1999).
22 See the "Memorial atribuido a Hernando de Magallanes y Ruy Faleiro sobre el descubrimiento de las islas del Maluco", AGI, Patronato, 34, R. 7. This was not the only proposal the monarch would receive. Alonso de Zuazo, a man of law, made a similar proposal in January 1518. See Zuazo's letter sent from Santo Domingo on January 22, 1518 (Gil, 2009, pp. 247-248).

23 "Capitulación y asiento del rey Carlos I con Fernando de Magallanes y Ruy Faleiro para dirigir la armada del Maluco hacia las Islas de las Especias" (Valladolid, 22nd March 1518), AGI, Patronato, 34, R. 1. On the capitulations of Valladolid, see Ramos Pérez (2019).

24 "Instrucción del Rey a Magallanes y a Falero para el descubrimiento de las islas del Maluco", AGI, Patronato, 34, R. 8.

25 On Haro and the interests of the Burgos merchants in the discovery of the Strait of Magellan, see Gallez (1991).

26 About Rui Faleiro see the invaluable documentary work done by Juan Gil (2009, pp. 349-387) that also incorporates the list of books that made up the Faleiro's magnificent (scientific) library, including books on astronomy (Ptolemy, Al-Farghani, Zacuto, Albumasar), arithmetic (Boethius) and astrology (Jerónimo Torrella, Juan Gil), among others. On the hypothetical library of Magellan, see the recent study by Rui Loureiro (2019).

27 These three methods are also explained in the short Pigafetta's Treatise of Navigation, which also gives elementary instructions on how to use the armillary sphere and how to know the latitude (Stanley, 2010, pp. 167 and ff.). On the problem of longitude in the framework of Tordesillas, see Reis (1994).

28 A copy of this document can be found at AGI, Patronato, 262, R.3. For a study on this document, see Mota (1953) and Laguarda Trías $(1959,1975)$.

29 Góis refers to Faleiro in these terms in chapter 37 of the fourth part of his Crónica del rey D. Manuel (Góis, 1567, f. 45v).

30 About the Faleiro brothers, see Mota (1975). About Francisco Faleiro, see Collins (2013).

31 Pigafetta also tells how Magellan, in the company of the King of Butuan, "showed him the sea chart and the ship compass, and informed him how he had found the strait to come there" (Stanley, 2010, p. 77).

32 In his Treaty of Navigation he stated: "At the present time the pilots content themselves with knowing the latitude; and are so proud that they will not hear speak of longitude" (Stanley, 2010, p. 167).

33 The objective of this section is not to make an exhaustive study of Magellan's voyage, but briefly describe some of the highlights from Magellan's departure to his death. For this purpose, I have followed the main sources of the expedition -in Stanley (2010) - as well as three excellent studies: Castro, Hamon and Thomaz (2007), Garcia (2007), and Gil (2009). Although novelized, the stories of Stefan Zweig (2016) y Laurence Bergreen (2003) are also excellent descriptions of the voyage.

34 See "Relación de la gente embarcada en las naos enviadas para el descubrimiento de la Especiería, de las que iba por capitán mayor Fernando de Magallanes", AGI, Patronato, 34, R. 6. Among the crew were 139 Spaniards, 31 Portuguese, 26 Italians, 9 Greeks, 5 Flemish, 4 Germans, 2 Irish, 2 black slaves, 2 mestizos, 1 English, 1 Indian and 1 Malaysian slave. See Gil (2009, p. 277, 2017).

35 On the technical characteristics of the boats that made up the expedition, see Fernández Vial and Fernández Morente (2001) and Fernández Vial (2019).

36 See "Traslado de la información presentada por poderes por Álvaro de la Mezquita, acerca de la toma de la nao San Antonio por Gaspar de Quesada y Juan de Cartagena, el 1 de abril de 1520" (22nd May 1521), AGI, Patronato, 34, R. 17.

37 For a study on the crossing of the Pacific, see Nunn (1934). A more recent study is found in Comellas (2012).

38 In the last Spanish edition, we read the opposite: "dos estrellas muy grandes y muy brillantes" ("two very big and very bright stars"), Pigafetta (2019, p. 139). These two groups of stars would take on special prominence in the early years of the 20th 
century thanks to the astrophysicist Henrietta Swan Leavitt and her work on the location of very distant variable stars within the Magellanic Clouds, so named in honour of the expedition and its first recorded sighting.

39 See "Carta del capitán Antonio de Brito a Juan III de Portugal informando sobre el paso de las naos que quedaban de la expedición de Magallanes" (May 6, 1523), Arquivo Nacional Torre do Tombo, PT/TT/GAV/18/2/25. See Ramos Coelho (1892). According to Damião de Góis, Brito gave them a good deal (Góis, 1567 , p. 46)

40 See "Carta de Gonzalo Gómez de Espinosa a Carlos I, narrando las vicisitudes del periplo en solitario de la nao Trinidad por el Pacífico Norte, y su prisión por los portugueses" (January 12, 1525), AGI, Indiferente, 1528, N. 2. Only three survivors arrived in Castile with Espinosa: Ginés de Mafra - who supposedly kept the papers of San Martín_-, León Pancaldo and Juan Rodríguez Sordo. See also "Interrogatorios a los tripulantes supervivientes de la nao "Trinidad", de la armada de Magallanes, sobre lo acontecido en su retorno de las Molucas" (August 2, 1527), AGI, Patronato, 34, R. 27. See Correia (1861, p. 634). An anonymous Genoese pilot, probably Leon Pancaldo, described the voyage of the Trinity. See Stanley (2010, pp. 1-29). The voyage of the Trinidad is also described in Ginés de Mafra's narrative (Elcano et al., 2018, pp. 181-183).

41 Francisco Albo simply says that "they [the Portuguese] reckoned this day as Thursday, and so I believe that we had made a mistake of a day", Stanley (2010, p. 235). Pigafetta, who "having always been in good health" and "had every day, without intermission, written down the day that was current" was very surprised by the news. He goes on to say: "But we were afterwards advised that there was no error on our part, since as we had always sailed towards the west, following the course of the sun, and had returned to the same place, we must have gained twenty-four hours, Stanley (2010, p. 161). That "gain" would later be remembered by Jules Verne in Around the World in Eighty Days (1872) when the protagonist of the story, Phileas Fogg, arrived in London a day earlier than planned by sailing — yes, you guessed it - eastwards and gaining a day. In the case of the Victoria, he had not had an advantage, but had lost a day because of having sailed in the opposite direction to the rotary movement of the Earth on itself. This phenomenon is explained by Peter Martyr d'Anghiera in the seventh book of the fifth decade of his De Orbe Novo (Anghiera, 1912, pp. 170-171).

42 See "Relación de tripulantes de la Armada enviada al descubrimiento de la Especiería fallecidos, desertores o dejados en las Molucas" (July 1522), AGI, Patronato, 34, R. 11. On the identity of the 18 sailors, see Gil (2009, pp. 303-305).

43 See "Información recibida por el alcalde de casa y corte, Santiago Díaz de Leguizamo, en que declaran el capitán de la nao "Victoria" Juan Sebastián Elcano, Francisco Albo y Fernando de Bustamente, sobre distintos pormenores del viaje de la primera vuelta al mundo" (October 18, 1522), AGI, Patronato, 34, R. 19.

44 See the coat of arms of Gonzalo Gómez de Espinosa, AGI, MP-Escudos, 231. Recently reproduced in Fernández Torres (2019, p. 151)

45 See "Carta de Juan Sebastián Elcano al emperador Carlos V" (September 6, 1522), AGI, Patronato, 48, R. 20.

46 For a more detailed analysis of the Toreno chart, see MartínMerás (1993: 87), Cerezo (1994a, pp. 173-174), and Sánchez (2013, pp. 175-176)

47 The historian Dejanirah Couto has suggested that there are several indications that the Hazine chart no. 1825 may have been part of the set of maps that Magellan carried on board the expedition. Since it could also have been Pigafetta who took it to Istanbul (Couto, 2013).

48 According to the narrative of an anonymous Portuguese pilot, "some called it the Strait of Magalhaens, because our captain was named Fernando de Magalhaens" (Stanley, 2010, p. 31).

49 For a new cartographic discovery related to the Padrón Real of the 1520s, see Manso (2019b).

\section{REFERENCES}

Acosta, J. (1880) [1590] The Natural and Moral History of the Indies. London: Hakluyt Society.

Albuquerque, L. (1965) Os guias náuticos de Munique e Évora. Junta de Investigações do Ultramar, Lisbon.

Albuquerque, L. (1973) "O Tratado de Tordesilhas e as dificuldades técnicas da sua aplicação rigorosa." Separata da Revista da Universidade de Coimbra, 23, pp. 1-21.

Albuquerque, L. (1988) Astronomical Navigation. Lisboa: Comissão Nacional para as Comemorações dos Descobrimentos Portugueses.

Anghiera, P. M. (1912) [1494-1525] De orbe novo. New York/London: G. P. Putnam's Sons.

Argensola, B. L. (1609) Conquista de las islas Molucas. Madrid: por Alonso Martin.

Barros, J. (1777) Decadas da Asia. Lisboa: Regia Officina Typografica.

Bergreen, L. (2003) Over the Edge of the World: Magellan's Terrifying Circumnavigation of the Globe. New York: William Morro.

Branquinho, I. (1999) "O Tratado de Tordesilhas e a Questão das Molucas." Mare Liberum, 8, pp. 1-26.

Butterfield, H. (1949) The Origins of Modern Science, 1300-1800. London: G. Bell.

Camões, L. (1819) [1572] Os Lusíadas. Paris: Na Officina Typographica de Firmino Didot.

Castanheda, F. L. (1833) [1551] História do descobrimento e conquista da India pelos portugueses. Lisboa: Typographia Rollandiana.

Castañeda, F. P. (1973) "El Tratado de Alcaçovas y su interpretación hasta la negociación del Tratado de Tordesillas." In: El Tratado de Tordesillas y su proyección, Tomo I. Valladolid: Universidad de Valladolid, pp. 103-115.

Castro, X., Hamon, J. and Thomaz, L. F. (2007) Le voyage de Magellan (1519-1522). La relation d'Antonio Pigafetta \& autres témoignages. Paris: Chandeigne.

Cerezo Martínez, R. (1994a) La cartografía náutica española en los siglos XIV, XV y XVI. Madrid: CSIC.

Cerezo Martínez, R. (1994b) "El meridiano y el antimeridiano de Tordesillas en la geografía, la náutica y la cartografía." Revista de Indias, 54 (202), pp. 509-542. doi: https://doi.org/10.3989/ revindias.1994.i202.1118

Collins, E. (2013) "Francisco Faleiro and Scientific Methodology at the Casa de la Contratación in the Sixteenth Century." Imago Mundi, 65 (1), pp. 25-36. doi: https://doi.org/10.1080/0308569 4.2013.731202

Colón, C. (1986) Los cuatro viajes: testamento Madrid: Alianza.

Comellas, J. L. (2012) La primera vuelta al mundo. Madrid: Rialp.

Correia, G. (1861) Lendas da India. Lisboa: Typographia da Academia Real das Sciencias.

Cortesão, A. (1973) “D. João II e o Tratado de Tordesillas.” Separata dos Anais do Clube Militar Naval, 1-3, pp. 1-12.

Cortesão, A. (1975) "As mais antigas cartografia e descrição das Molucas." In: A. T. da Mota, ed., A viagem de Fernão de Magalhães e a questão das Molucas: actas do II Colóquio Luso-Espanhol de História Ultramarina. Lisboa: Junta de Investigações Científicas do Ultramar, pp. 49-74.

Cortesão, A. and Mota, A. T. da (1987) [1960] Portugaliae Мonumenta Cartographica, Vol. I, Lisboa: Imprensa Nacional-Casa da Moeda.

Couto, D. (2013) "Autour du globe? La carte Hazine n. ${ }^{\circ} 1825$ de la bibliothèque du Palais de Topkapi, Istanbul." Cartes \& Géomatique, 216, pp. 119-134.

Dear, P. (2001) Revolutionizing the Sciences: European Knowledge and its Ambitions, 1500-1700. London: Palgrave.

Denucé, J. (1908-1911) "Magellan: la question des Moluques et la première circumnavigation du globe." Mémoires de l'Académie Royale de Belgique, Segunda serie, Tomo IV: pp. 1-433.

Destombes, M. (1955) "The Chart of Magellan.” Imago Mundi, 12: 65-88. 
Díaz-Trechuelo, L. (1994) "El Tratado de Tordesillas y su proyección en el Pacífico.” Revista Española del Pacífico, 4, pp. 11-22.

Dos Reis, A. E. (1994) "O problema da determinação da longitude no Tratado de Tordesilhas." Mare Liberum, 8, pp. 19-32.

Elcano, J. S., Pigafetta, A., Transilvano, M., Albo, F. and Mafra G. (2018) [2012] La primera vuelta al mundo. Madrid: Miraguano Ediciones-Ediciones Polifemo.

Ezquerra, R. (1973) "Las Juntas de Toro y Burgos.” In: El Tratado de Tordesillas y su proyección. Valladolid: Universidad de Valladolid, Tomo I, pp. 149-170.

Fernández Armesto, F. (2010) 1492: el nacimiento de la modernidad. Barcelona: Debate.

Fernández de Oviedo, G. (1852) Historia general y natural de las Indias. Tomo 1, 2. ${ }^{\text {a }}$ parte. Madrid: Real Academia de la Historia.

Fernández Duro, C. (1884) "La situación del cabo de San Agustín en el Brasil, el año de 1515.” Boletín de la Sociedad Geográfica, $16,(1)$, pp. 25-30.

Fernández Navarrete, M. (1837) Colección de los viajes y descubrimientos que hicieron por mar los españoles desde fines del siglo $X V$ (Tomo IV). Madrid: Imprenta Nacional.

Fernández Navarrete, M. (1853) Colección de los viajes y descubrimientos que hicieron por mar los españoles (Tomo I). Madrid: Imprenta Nacional.

Fernández Navarrete, M. (1944) Viaje de Magallanes y de Sebastián de Elcano alrededor del mundo. Buenos Aires: Emecé Editores.

Fernández Torres, A. (2019) El viaje más largo. La primera vuelta al mundo. Madrid: Sociedad Mercantil Estatal de Acción Cultural.

Fernández Vial, I. (2019) "Las naves.” In: A. Fernández Torres, ed., El viaje más largo. La primera vuelta al mundo. Madrid: Sociedad Mercantil Estatal de Acción Cultural, pp. 73-77.

Fernández Vial, I. and Fernández Morente, G. (2001) La primera vuelta al mundo. La nao Victoria. Sevilla: Muñoz Moya editores.

Fonseca, L. A. da and Ruiz Asencio, J. M. (1995) Corpus documental del Tratado de Tordesillas. Valladolid: Sociedad V Centenario del Tratado de Tordesillas.

Gallez, P. (1991) Cristóbal de Haro: banqueros y pimenteros en busca del estrecho magallánico. Bahía Blanca: Instituto Patagónico.

Garcia, J. M. (2007) A viagem de Fernão de Magalhães e os Portugueses. Lisboa: Editorial Presença,

Garcia, J. M., ed. (2008) O Livro de Francisco Rodrigues: o primeiro atlas do mundo moderno. Porto: Editora da Universidade do Porto.

García de Céspedes, A. (1606) Hydrografia. Madrid: en casa de Iuan de la Cuesta.

García Redondo, J. M. (2018) Cartografía e Imperio. El Padrón Real y la representación del Nuevo Mundo. Madrid: Ediciones Doce Calles.

Gaspar, J. A. (2012a) "De la Méditerranée à l'océan: nouveaux problèmes, nouvelles solutions.” In: C. Hofmann, H. Richard and E. Vagnon, eds., L'Âge d'or dês cartes marines. Quand l'Europe découvrait le monde. Paris: Seuil \& Biblithèque nationale de France, pp. 126-130.

Gaspar, J. A. (2012b) "Blunders, Errors and Entanglements: Scrutinizing the Cantino Planisphere with a Cartometric Eye." Imago Mundi, 64 (2), pp. 181-200. doi: https://doi.org/10.1080/03085 694.2012.673762

Gaspar, J. A. and Sánchez, A. (2013) "Do Mediterrâneo ao mundo. Os alvores da cartografia ibérica do Renascimento.” In: H. Leitão, ed., $360^{\circ}$ Ciência descoberta, Lisboa: Fundação Calouste Gulbenkian, pp. 64-91.

Gil, J. (1998) "Diplomacia y cartografía en el Tratado de Tordesillas." In: Limites do Mar e da Terra: Actas VIII Reunião Internacional de História da Náutica e Hidrografia. Cascais: Patrimonia, pp. 153-162.

Gil, J. (2009) El exilio portugués en Sevilla. De los Braganza a Magallanes. Sevilla: Fundación Cajasol.

Gil, J. (2017) "Los hombres y el rol del viaje de Magallanes." In: In medio Orbe. Sanlúcar de Barrameda y la I Vuelta al Mundo.
Actas del II Congreso Internacional sobre la I Vuelta al Mundo, celebrado en Sanlúcar de Barrameda (Cádiz) los días 20 y 21 de septiembre de 2017. Sevilla: Junta de Andalucía, Consejería de Cultura, and Ayuntamiento de Sanlúcar de Barrameda, pp. 31-58.

Góis, D. (1567) Chronica do felicisimo Rei Dom Emanuel. Lisboa: Cuarta parte.

Gutiérrez Escudero, A. (1990) América: descubrimiento de un mundo nиevo. Madrid: Istmo.

Hampe Martínez, T. (1999) "El Tratado de Tordesillas (1494) y sus antecedentes: los grandes descubrimientos del siglo XV." $R e$ vista Peruana de Derecho Internacional, 49 (113), pp. 45-83.

Heawood, E. (1921) "The World Map before and after Magellan's Voyage." The Geographical Journal, 57 (6), pp. 431-442. doi: https://doi.org/10.2307/1780791

Herrera, A. (1601) Historia general de los hechos de los castellanos en las islas y Tierra Firme del Mar Océano. Madrid: Imprenta Real.

Hidalgo Nieto, M. (1942) "La cuestión hispano portuguesa en torno a las islas Molucas." Revista de Indias, 9, pp. 429-462.

Higueras Rodríguez, M. D. (2018) La vuelta al mundo de Magallanes-Elcano: la aventura de lo imposible, 1519-1522. Madrid/Barcelona: Ministerio de Defensa, CSIC and Lunwerg.

Hooykaas, R. (1987) "The Rise of Modern Science: When and Why?" The British Journal for the History of Science, 20, pp. 453-473. doi: https://doi.org/10.1017/s0007087400024225

Insua, P. (2019) El orbe a sus pies. Magallanes y Elcano: cuando la cosmografía española midió el mundo. Barcelona: Ariel.

Juan, J. and Ulloa, A. (1972) [1749] Dissertacion historica, y geographica sobre el Meridiano de Demarcación entre los Dominios de España, y Portugal, y los parages por donde passa en la America Meridional, conforme à los Tratados, y derechos de cada Estado, y las mas seguras, y modernas observaciones. Madrid: Instituto Histórico de Marina.

Koyré, A. (1962) Du monde clos à l'univers infini. Paris: PUF

Laguarda Trías, R. A. (1959) "Las tablas náuticas de la expedición de Magallanes-Elcano." Boletín de la Real Academia de la Historia, 144 (1), pp. 57-73.

Laguarda Trías, R. A. (1975) "Las longitudes geográficas de la membranza de Magallanes y del primer viajede circunnavegación.” In: A. T. da Mota, ed., A viagem de Fernão de Magalhães e a questão das Molucas. Lisboa: Junta de Investigações Científicas do Ultramar, pp. 135-178.

Laguarda Trías, R. A. (1991) El cosmógrafo sevillano Andrés de San Martín: inventor de las cartas esféricas. Montevideo: Imprenta Militar.

Lamb, U. (1974) "The Spanish Cosmographic Juntas of the Sixteenth Century." Terrae Incognitae, 6, pp. 51-64. doi: https://doi.org/10.1179/tin.1974.6.1.51

Las Casas, B. (1876). Historia de las Indias (Tomo IV). Madrid: Imprenta de Miguel Ginesta.

Latorre, G. (1923) Los españoles y portugueses en ultramar: la cuestión del Maluco. Sevilla: Publicaciones del Centro Oficial de Estudios Americanistas de Sevilla, vol. XI.

Levillier, R. (1954) “New Light on Vespucci's third voyage." Imago Mundi, 11 (1), pp. 37-46.

Linden, H. V. (1916) "Alexander VI and the Demarcation of the Maritime and Colonial Domains of Spain and Portugal, 14931494." The American Historical Review, 22 (1), pp. 1-20. doi: https://doi.org/10.2307/1836192

López de Gómara, F. (1979) [1552] Historia General de las Indias y vida de Hernán Cortés. Caracas: Biblioteca Ayacucho.

Loureiro, R. (2019) Em demanda da biblioteca de Fernão de Magalhães. Lisboa: Biblioteca Nacional de Lisboa.

Magnaghi, A. (1927) "La prima rappresentazione delle Filippine e delle Molucche dopo il ritorno Della spedizione di Magellano, nella carta costruita nel 1522 da Nuño García de Toreno, conservata nella Biblioteca di S. M. il Re in Toreno." In: Atti del X Congresso Geografico Italiano, vol. 1. Milán: Touring Club Italiano, pp. 293-307. 
Manso, C. (2019a) "La cartografía de la expedición Magallanes-Elcano." In: Actas del Congreso Internacional de Historia "Primus circumdedisti me” (Valladolid, 2018). Madrid: Ministerio de Defensa, pp. 271-297.

Manso, C. (2019b) "Mapa del Nuevo Mundo con la línea divisoria trazada por Alejandro VI: reproducción de un planisferio anónimo del primer tercio del siglo XVI." Revista de Estudios Colombinos, 15, pp. 31-44.

Manzano Manzano, J. (1942) "El derecho de la Corona de Castilla al descubrimiento y conquista de las Islas de Poniente." Revista de Indias, 9, pp. 397-427.

Marques de Almeida, A. A. (1995) "Conhecimento e representação do Mundo no tempo de Tordesilhas." In: B. Schröter and K. Schüller, ed., Tordesillas y sus consecuencias: la política de las grandes potencias europeas respecto a América latina (14941898). Frankfurt am Main: Vervuert, pp. 29-39.

Martín-Merás, M. L. (1993) Cartografía marítima hispana: la imagen de América. Madrid: Lunwerg.

Martins, J. P. O. (1879), História da Civilização Ibérica. Lisbon: Bertrand.

Medina, J. T. (1920) [1888] El descubrimiento del océano Pacífico: Hernando de Magallanes y sus compañeros. Santiago de Chile: Imprenta Elzeviriana.

Medina, P. (1549) Libro de las grandezas y cosas memorables de España. Sevilla: en casa de Dominico de Robertis.

Millás Vallicrosa, J. M. (1991) [1949] "El cosmógrafo Jaime Ferrer de Blanes." In: Estudios sobre historia de la ciencia española. Barcelona: CSIC, pp. 455-468.

Moreno Madrid, J. M. and Leitão, H. (2020) Atravessando a Porta do Pacífico. Roteiros e Relatos da Travessia do Estreito de Magalhães, 1520-1620. Lisboa: By the Book.

Moreno Martín, J. M. (2019a) A vueltas con el mundo. Los mapas de Magallanes y Elcano. Madrid: Ministerio de Defensa.

Moreno Martín, J. M. (2019b) "Los mapas del viaje de Magallanes y Elcano: bocetos de un nuevo mundo." In: Fuimos los primeros. Magallanes, Elcano y la vuelta al mundo. Madrid: Ministerio de Defensa, pp. 45-66.

Mota, A. T. Da (1973) "Reflexos do Tratado de Tordesilhas na cartografia náutica do século XVI." Separata da Revista da Universidade de Coimbra, XXIII, pp. 3-15.

Mota, A. T. da (1975) "Contribuição dos irmãos Rui e Francisco Faleiro no campo da náutica em Espanha.” In: A. T. da Mota, ed., A viagem de Fernão de Magalhães e a questão das Molucas. Lisboa: Junta de Investigações Científicas do Ultramar, pp. 315-341.

Mota, A. T. da (1986) O Regimento da altura de Leste-Oeste de Rui Faleiro: Subsídios para o Estudo Náutico e Geográfico da Viagem de Fernão de Magahlães. Lisboa: Edições Culturais de Marinha.

Muñoz Pérez, J. (1973) “La 'frontera astronómica' de Tordesillas." In: El Tratado de Tordesillas y su proyección. Valladolid: Universidad de Valladolid, Tomo II, pp. 197-215.

Nunn, G. E. (1934) “Magellan's Route in the Pacific.” Geographical Review, 24 (4), pp. 615-632.

Ozanne, H. (1989) "La découverte cartographique des Moluques." In: M. Pelletier, ed., Géographie du monde au Moyen Âge et à la Renaissance. Paris: Éditions du CTHS, pp. 217-228.

Pérez de Tudela, J. (1985) "Razón y génesis del Tratado de Tordesillas." In: Tratado de Tordesillas. Madrid: Testimonio, pp. 3-36.

Pérez Embid, F. (1948) Los descubrimientos en el Atlántico y la rivalidad castellano-portuguesa hasta el Tratado de Tordesillas. Sevilla: Escuela de Estudios Hispano-Americanos.

Pigafetta, A. (2019) [1524] La primera vuelta al mundo. Madrid: Alianza.

Pino Ycaza, G. (1945) La bula de Alejandro VI y el Tratado de Tordesillas. Guayaquil: Imprenta de la Universidad.

Portuondo, M. M. (2019) "Un mundo nuevo: La revolución en la geografía y la historia natural.” In: A. Fernández Torres, ed., El viaje más largo. La primera vuelta al mundo. Madrid: Sociedad Mercantil Estatal de Acción Cultural, pp. 329-335.
Ramos Coelho, J. (1892) Alguns documentos do Archivo Nacional da Torre do Tombo acerca das navegações e conquistas portuguezas. Lisboa: Imprensa Nacional.

Ramos Pérez, D. (2019) Magallanes en Valladolid. La Capitulación. Valladolid: Ediciones Universidad de Valladolid.

Remesal, A. (1994) 1494, La Raya de Tordesillas. Salamanca: Junta de Castilla y León.

Rumeu de Armas, A. (1992) El Tratado de Tordesillas. Madrid: Mapfre.

Sánchez, A. (2009) “De la 'cartografía oficial' a la 'cartografía jurídica': la querella de las Molucas reconsiderada, 1479-1529." Nuevo Mundo Mundos Nuevos [Online], Debates. doi: https:// doi.org/10.4000/nuevomundo.56899

Sánchez, A. (2013) La Espada, la cruz y el Padrón. Soberanía, fe y representación cartográfica en el mundo ibérico bajo la Monarquía Hispánica, 1503-1598. Madrid: CSIC.

Sánchez, A. (2016) "Science by Regimento: Standardising Long-Distance Control and New Spaces of Knowledge in Early Modern Portuguese Cosmography." Early Science and Medicine, 21, pp. 133-155. doi: https://doi.org/10.1163/15733823$02123 \mathrm{p} 03$

Sánchez, A. (2018) "Charts for an Empire. A Global Trading Zone in Early Modern Portuguese Nautical Cartography." Centaurus, 60, pp. 173-188. doi: https://doi.org/10.1111/1600-0498.12198

Sandman, A. (2001) Cosmographers versus Pilots: Navigation, Cosmography, and the State in Early Modern Spain. Ph. D. Thesis, University of Wisconsin.

Sandman, A. (2007) "Spanish Nautical Cartography in the Renaissance." In: D. Woodward, ed., The History of Cartography: Cartography in the European Renaissance. Chicago: The University of Chicago Press, vol. 3, pp. 1095-1142.

Santa Cruz, A. (1920-1923) Crónica del Emperador Carlos V, vol. 1. Madrid: Imprenta del Patronato de Huérfanos de Intendencia e Intervención Militares.

Serrão, J. V. (1995) “O Tratado de Tordesillas visto de Portugal.” In: L. A. Ribot, ed., El Tratado de Tordesillas y su época. Valladolid: Junta de Castilla y León, Tomo I, pp. 3-8.

Serrera, R. M. (2019), "La vuelta al mundo y la conquista de México: la plena dimensión continental de América (1519-1522)." In: A. Fernández Torres, ed., El viaje más largo. La primera vuelta al mundo. Madrid: Sociedad Mercantil Estatal de Acción Cultural, pp. 323-327.

Shapin, S. (1996) The Scientific Revolution. Chicago: University of Chicago Press.

Soler, I. (2015) El sueño del rey. Viajes y mesianismo en el Renacimiento peninsular. Barcelona: Acantilado.

Stanley, H. E. J. ed. (2010) [1874] The First Voyage Round the World by Magellan. Cambridge: Cambridge University Press.

Torodash, M. (1971) "Magellan Historiography." Hispanic American Historical Review, 51 (2), pp. 313-335. doi: https://doi. org/10.2307/2512478

Torodash, M. (1995) "Magellan Historiography. Some Twenty Years Later.” In: F. A. Dutra and J. C. dos Santos, eds., The Portuguese and the Pacific. International Colloquium at Santa Barbara. Santa Bárbara: University of California, pp. 11-16.

Tratado de Tordesillas. (1973). Madrid: Ministerio de Educación y Ciencia. Facsimile edition.

El Tratado de Tordesillas. 1494. (2007) Madrid: Ministerio de Cultura. Facsimile edition in Spanish and Portuguese.

Trueba, E. y Llavador, J. (1997) "Geografía conflictiva en la expansión marítima luso-española, siglo XVI." Revista de Historia Naval 15 (58), pp. 19-38.

Turnbull, D. (1996) "Cartography and Science in Early Modern Europe: Mapping the Construction of Knowledge Spaces." Imago Mundi, 48, pp. 5-24. doi: https://doi. org/10.1080/03085699608592830

Van Duzer, C. (2010) Johann Schöner's Globe of 1515: Transcription and Study. Philadelphia: American Philosophical Society

Varela, C. (1988) Colón y los florentinos. Madrid: Alianza.

Varela Marcos, J. (1994) "La cartografía del segundo viaje de Colón 
y su decisiva influencia en el Tratado de Tordesillas.” In: J. Varela, ed., El Tratado de Tordesillas en la cartografía histórica. Valladolid: Junta de Castilla y León, pp. 85- 108.

Varela Marcos, J. (1996) El Tratado de Tordesillas en la política atlántica castellana. Valladolid: Universidad de Valladolid.

Vigneras, L. A. (1962) “The Cartographer Diogo Ribeiro.” Imago
Mundi, 16, pp. 76-83.

Zilsel, E. (1942) "The Sociological Roots of Science." American Journal of Sociology, 47 (4), pp. 544-562. doi: https://doi. org/10.1086/218962

Zweig, S. (2016) [1938] Magellan. Conqueror of the Seas. Lexington: Mass Plunkett Lake Press. 